\title{
قصيدة القتاع في شعر عبد العزيز عسير
}

م. م. رؤى عبد الامير رحمة عطية العبادي، جامعة البصرة، كلية التربية/القرنة، قسم اللغة العربية الباحثة: خديجة فارس عبد العالي، مديرية تربية البصرة، قسم تربية القرنة

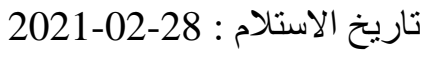

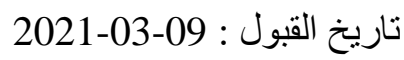

\section{ملخص البحث}

شكَّلَ البحث دراسة ظاهرة في شعر شاعر عراقيّ حديث ألا وهي (القناع)، و اختارَتِ الباحثتانِ دراسة

هذه الظاهرة في شعر الثاعر عبد العزيز عسير لأنََُّ استخدمَ القناع بكثرة في قصائدهِ؛ لأنَّ الحقبة التي عاشها تمثَّتُْْ بالضغط السلطويّ؛ لذا لجأ الثاعر إلى هذه الوسيلة (القناع) كي يُعبّرِ عمّا يُرِيد بصورة غير مُباثِرَة، إذْ يتكلَّم عن ظروفهِ وظروف مجتمعهِ الذي ينتمي إليه بهامشٍ مِن الحريَّةِ دون خوفٍ مِن المُلاحقَة والمُراقَبَّة. فقد استخدمَ الشاعر القناع على لسان الإنسان تارة وعلى لسان الحيوان تارة أخرى، وقذْ أجاد الحديث مِن وراء قتاعهِ حتى تمكَّنَ مِن إيصال صوتهِ وإظهار الظلم الذي كانَ يعاني منهُ هو و مجتمعه. وقْْ تمكَّنَ الثاعر مِن الرَّبط بينَ الأزمنة والثَّْضصيات داخل قناعِِ، إذْ نجده يربط بينَ ما حصلَ في الماضي وما يحصل في الوقت الحاضر، وكذلكَّ ما عانتُهُ الشخصيات عبْرَ التأريخ وما يعانيه هو في زمانهِ. فالثاعر قد اختارَ القناع الذي يتَّصل بصوتِهِ، وجعل صوتَهُ وصوت الثخصية التي تقنَََّ بها صوتاً واحداً، إذ اختفى وراء تلك الثخصية مُعبّرًاً مِن خلالهِا عمّا يختلج نفسه.. الكلمات المفتاحية: قصيدة ، قناع ، شعر ، عراقي ، حديث 


\section{Al-Qina', The Mask in Abul-Azeez Aseer's poetry}

Assist. Lect. Ro'aa Abdul-Ameer Rahma Ateah Al-Abadi Univeruity of Basrah/ College of Education in Qurnah Department of Arabic Abstract

Researcher: Khadeja Fares Abdul-A'lli

Directorate of Basra Education

Department of Qurna Education

Emil; roaa482@yahoo.com

T;07811184823

Receipt date: 2021-02-28

Date of acceptance: 2021-03-09

\section{Abstract:}

The present paper studies a phenomenon in the verse of a modern Iraqi poet, namely (AlQina'/the Mask). The two researchers chose to study this phenomenon in the verse of the poet Abdul-Azeez Aseer because he used the mask frequently in his poems. Because the era in which he lived was marked by authoritarian pressure. So the poet resorted to this method (Al-Qina'/ the Mask) to express what he wanted indirectly, as he talks about his conditions and the conditions of his society to which he belongs with a margin of freedom without fear of prosecution and surveillance.

The poet uses the mask on the tongue of a man at one time and the tongue of animals at another, and he was able to speak well behind his mask until he was able to convey his voice and show the injustice that he and his society were suffering from. The poet was able to connect the times and the characters within his mask, as we find him linking between what happened in the past and what is happening in the present, as well as what the characters have suffered through history and what he suffers in his time. The poet chooses the mask that communicates with his voice, and made his voice and the voice of the character in which he disguised himself as one voice, as he disappeared behind that character, expressing through it what he was shaking himself.

Keywords: Poem, Mask, Poetry, Iraqi, Modern 
المقدمة:

شكَّل البحث محاولة لدر اسة ظاهرة في الثِِّعر الحديث ألا وهيَ (القناع)، فقد اشتخلَ شعر تللكَ الفترة بهذهِ

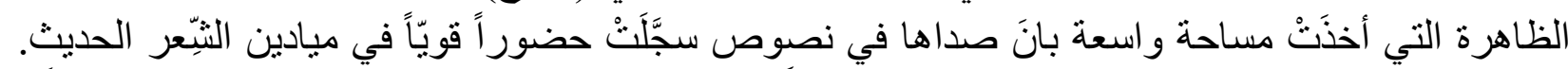

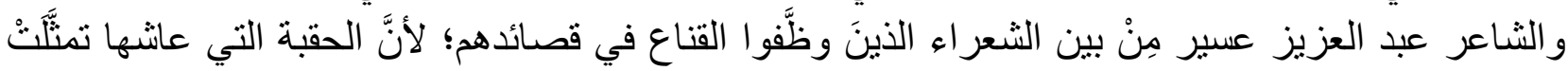

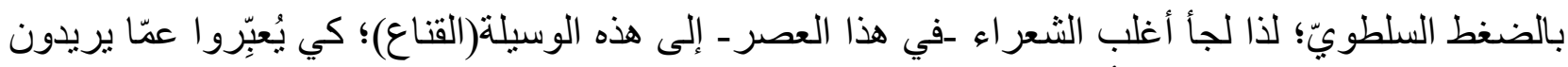

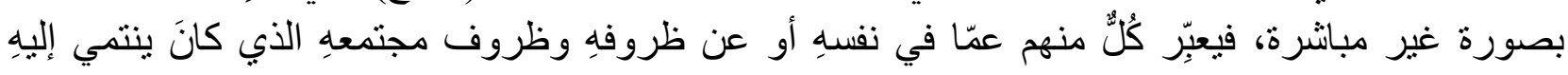

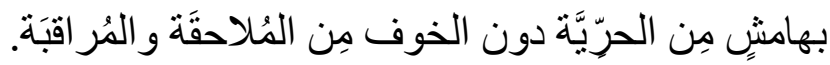

و البحث في مُجملهِ محاوَلة بسيطة للكثف عن ملامح القناع في القصيدة.

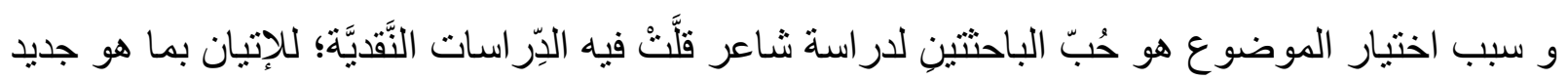
و الوقوف على ظاهرة بارزة ومهمَّة في شعرهِ و رَفْد المكتبة النَّقديَّة الحديثة ببحث يمكن تطويره إلى كتاب في في في المستقبل بإذن الله.

فوقعَ البحث على ظاهرة القناع في شعر عبد العزيز عسير؛ لأنَّهُ استعملَ القناع بكثرة في قصائدهِ وكانَتْ

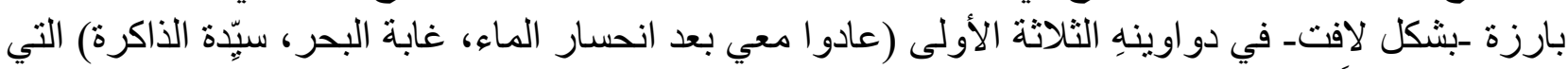

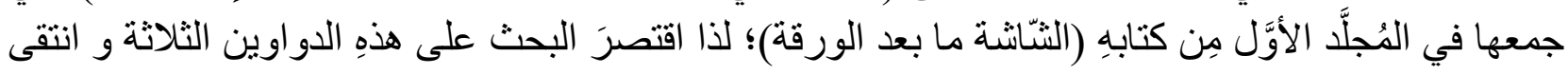
منها القصائد التي برزَ فيها القناع.

تضمَّنَ البحث بعد المُقدّمة التمهيد الذي تناولَ حياة الثّاعر، ومفهوم القناع الذي تبيَّنَتْ مصاديقُه عبر

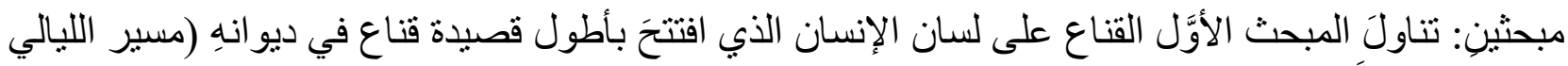

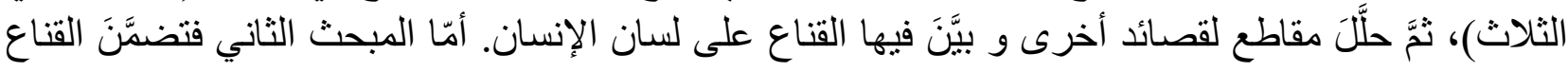
على لسان الحيوان وبيَّنَ مكنونات الثّاعر و خلجات نفسهِ عبْرَ ذللكَ القناع. وفي الخاتمة وقفت البحث على أبرز النَّائج التي تمَّ التوصُّل إليها.

الإِرِراسات السابقةة:

هنالكَ صعوبات واجهَت الباحثتينِ مِنْها قلَّة المصادر كون الموضوع غير مدروس مُسبقاً في شعر هذا

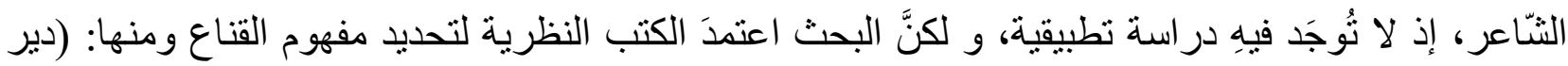
الملاك، لمحسن أطيمش)، و(القناع في الثعر العربي الحديث: در اسة في النظرية والتطبيق، لسامح الرواشدة)، واتجاهات الثعر العربي المعاصر لإحسان عباس). 
التمهـيد:

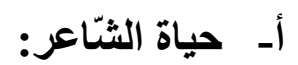

وُلِد الثَاعر عبد العزيز عسير سنة 1945م في البصرة في إحدى قرى أبي الخصيب (البراضعية)، ونشأ

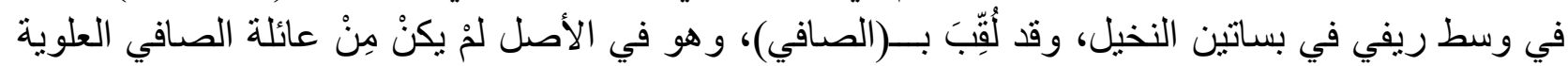

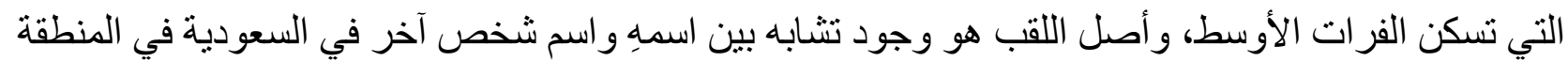

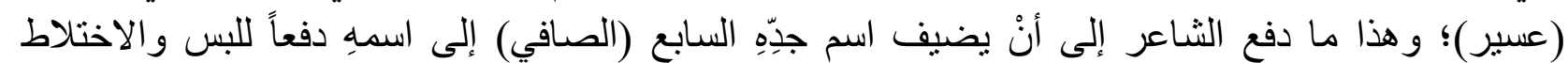
و التشابه في الأسماء.(اتصال هاتفي بالثاعر، 2021/2/10).

$$
\text { المدارس التي درَسَ فيها: }
$$

مدرسة فيصل الأوَّل الابتدائية، متوسطة التحرير للبنين، الاعدادية المركزية، كلية التربية/ قسم اللغة العربية (الآداب) / جامعة البصرة.

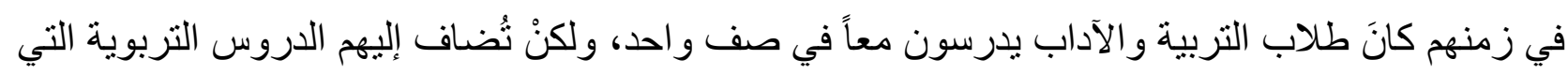
لا يدخل محاضر اتها طلاب الآداب.

* بدأ النشر في الصحف العر اقية في أو اسط الستينيات و هو طالب في الاعدادية المركزية. * نشر ابحاثاً في علم العروض في مجلة الأقلام أهمها بحث بعنوان (قضايا وآراء في العروض العربي) مجلة

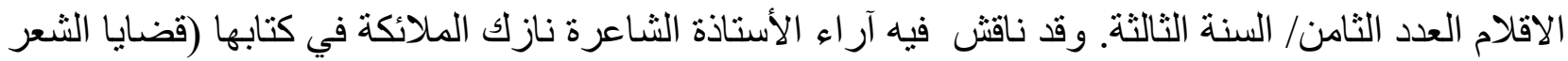

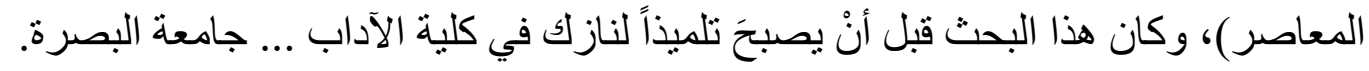
* من أساتذته في مدرسة فيصل الأول الابتدائية: الأستاذ عبد العزيز المعيبد، والملحن المعروف الأستاذ ياسين الر اوي، و الأستاذ المسرحي (مؤلف ومخرج): عبد الرزاق الثـاهين...

* من أساتذته في المتوسطة الثاعر كاظم مكي حسن...

* من أساتذته في الإعدادية الأستاذ كاظم نعمة التميمي، و الأستاذ قصي سالم علوان، و الأستاذ كاظم خليفة. * من أساتذته في الجامعة الناقد الدكتور عبد المنعم الزبيدي، والدكتور حسن البياتي، والدكتور ناصر حلاوي، وناز ك المانئكة...

* عمل مدرساً للغة العربية من سنة 1971 الى سنة 2014

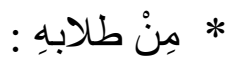
الثـاعر طالب عبد العزيز / تلميذه وجارهُ في السكن الثـاعر ر عد بندر / متوسطة العشار 
الدكتور حامد الظالمي / إعدادية الكفاح

الدكتور علي مجيد البديري / ثانوية الزبير.

رؤى عبد الامير رحمة/ ثانوية الفر اهيدي.(وهي حالياً تدريسية في كلية التربية/القرنة)

* سنة 1976 نُقِل إلى محافظة السليمانية ودرس فيها أربع سنوات، وتعلم اللغة الكردية.

*شارك في مجموعات شعرية أنطولوجية عن الثعر البصري منها كتاب (المرفأ الثعري)، و في جميع الكتب التي أصدر ها اتحاد الأدباء في البصرة أطولة

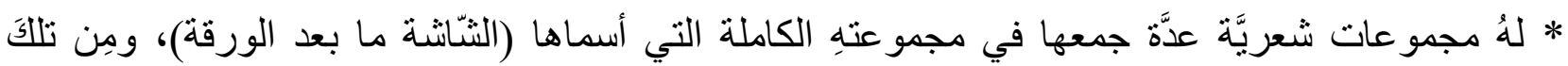
المجمو عات: (عادو ا معي بعد انحسار الماء، غلة غابة البحر، سيدة الذاكرة...)

* استُعين بهِ بوصفه مشرفاً لغوياً في أكثر من مجلة وصحيفة تابعة لاتحاد أدباء البصرة، منها صحف

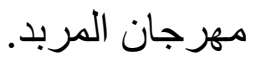

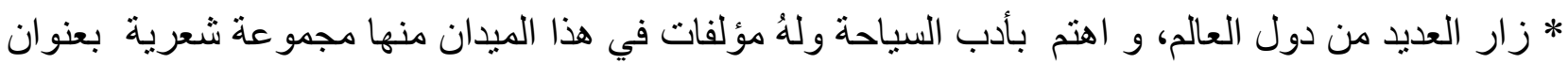

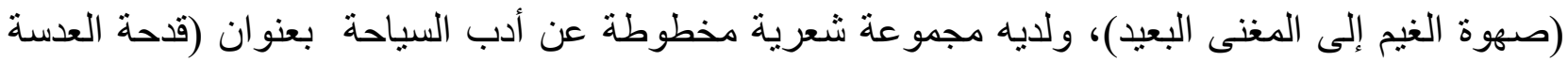

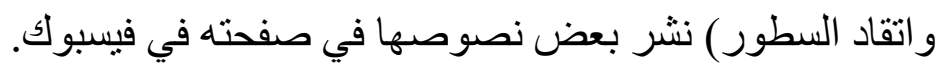

* اهنمَّ بدراسة أدب الثشانة، وله كتاب نقدي بعنوان(شاعرية فيسبوك) تتاولَ فيه النصوص التي تنشر في فيسبوك.

* من مؤلفاته المخطوطة كتاب (اللهجات العربية المعاصرة) وقد نشر منه عشر مقالات في صفحته على فيسبوك.

كتب الثاعر عبد العزيز عسير الثعر وهو في مرحلة المتوسطة، وبدأ بالنشر وهو في الإعدادية حتى أصبح

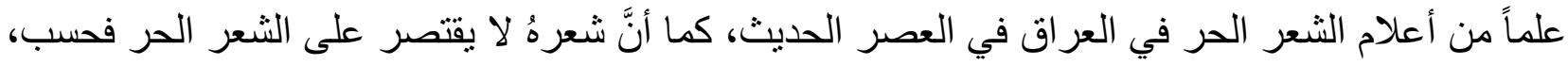

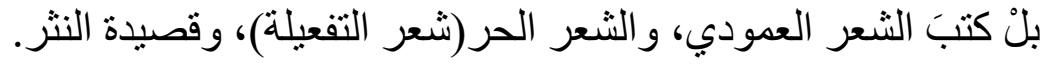

وفي عام 1971م أكمل دراسته الجامعية في كلية الآداب، وكان عضواً في اتحاد الادباء في عام إمار 1984م، كما فيا

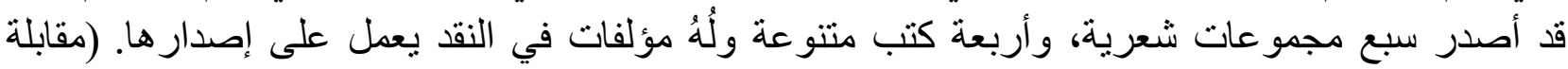

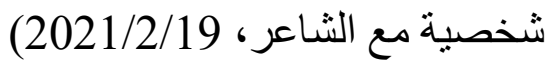

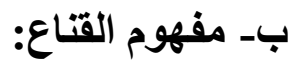

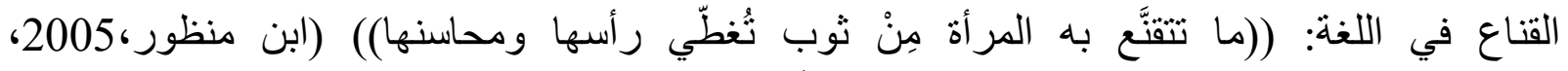

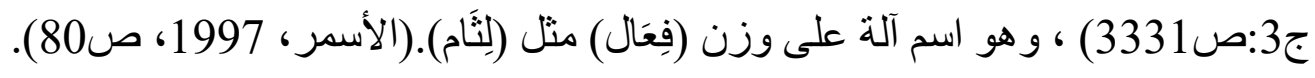

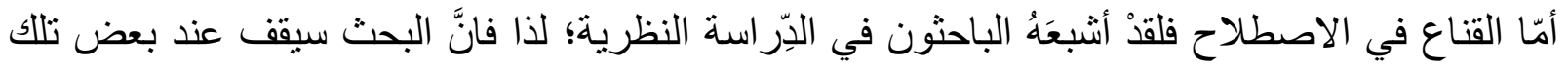

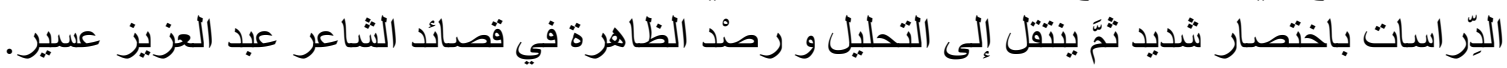




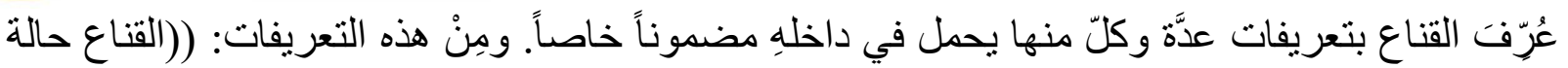

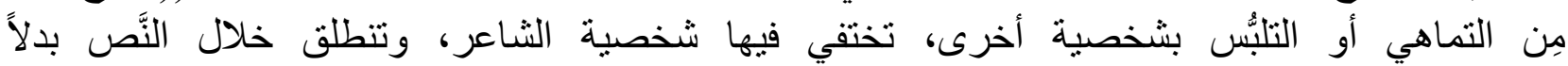

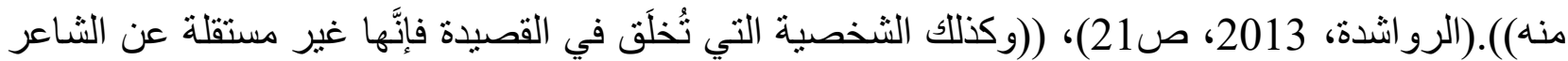

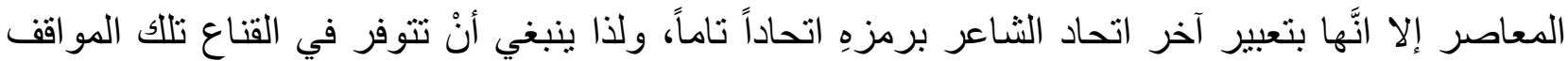

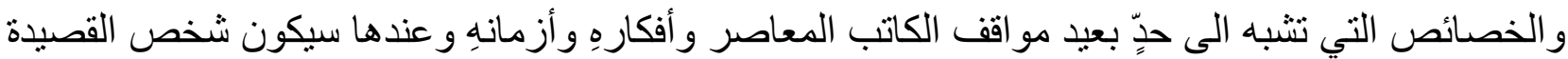

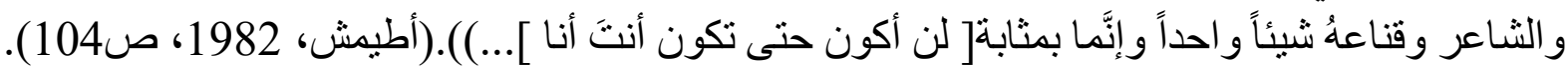

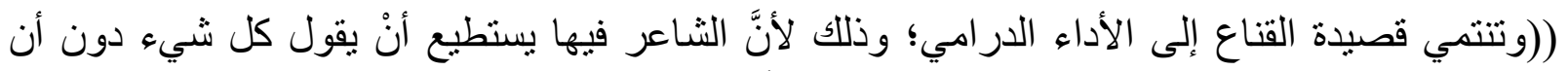

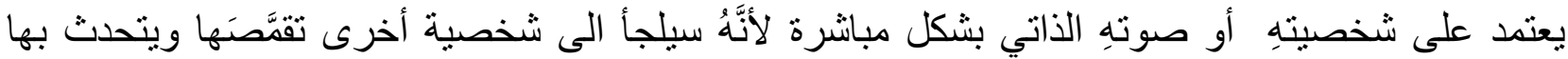

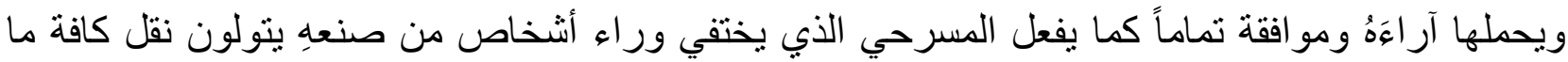

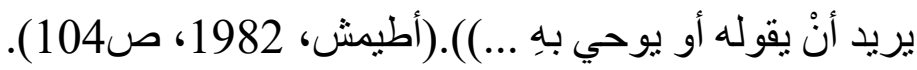

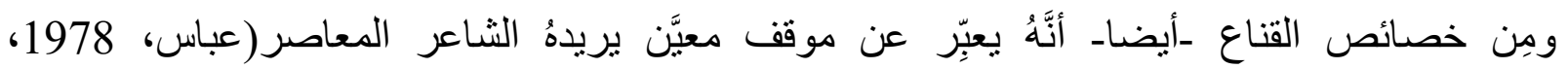

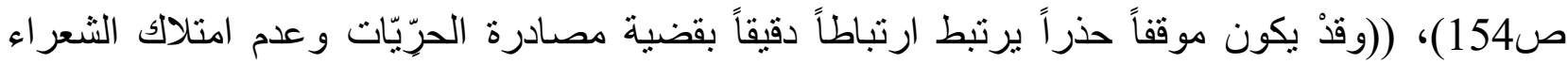

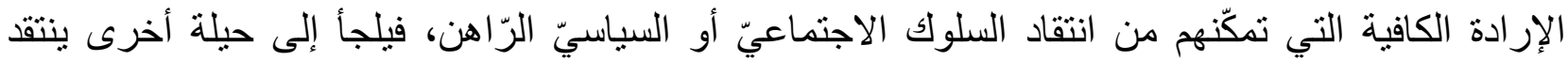

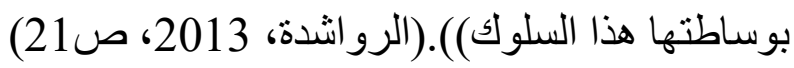

ويشِّّل القتاع حاجزاً بين الكاتب و المتلقي (القارئ) ؛ لذا فعملية التلقي لا تكون يسيرة وسط هذا الحاجز

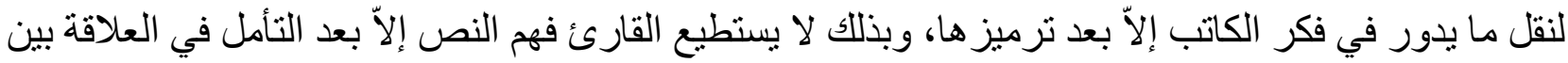

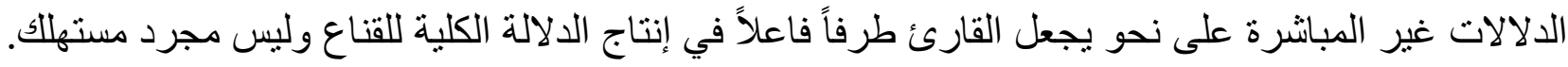

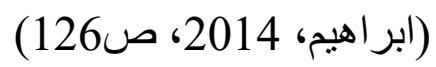

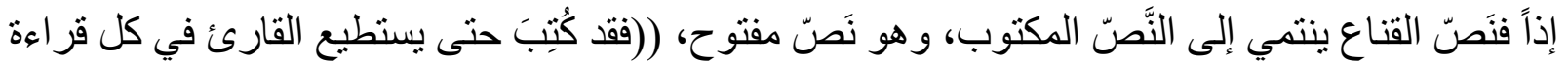

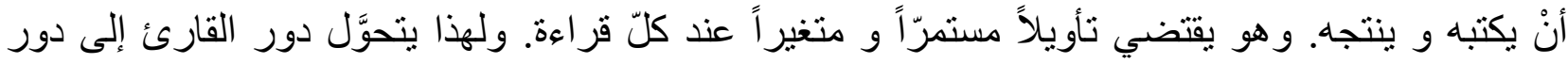

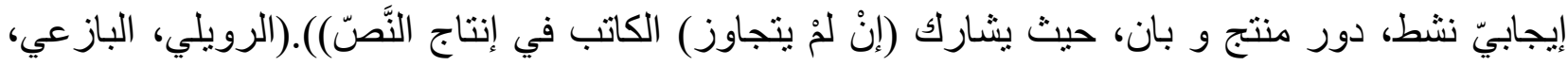

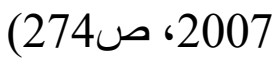

إنَّ للقناع اشكالاً مختلفة: منه ما هو تأريخي وما هو ديني و أسطوري وسياسي، ولقد تقنَّعَ الشعر اء بأنشكال

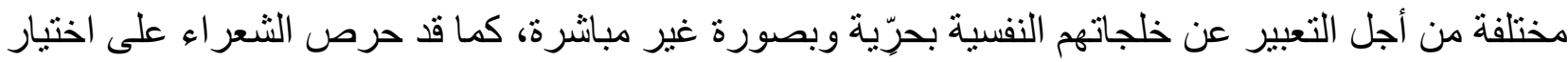

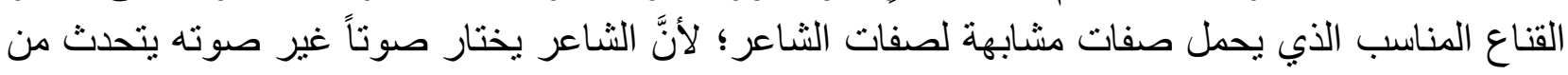

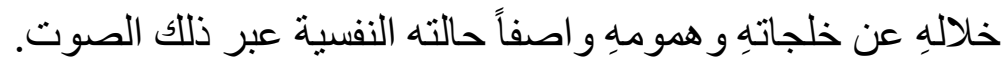




\section{المبحث الأول \\ القناع على لسان الإنسان}

من بين الشعر اء اللذين اتخذوا القناع وسيلة للتعبير هو الثاعر (عبد العزيز عسير)، فهو كسائر الثعر اء

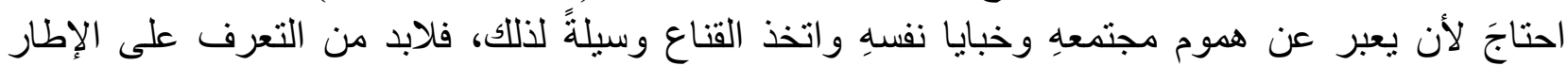

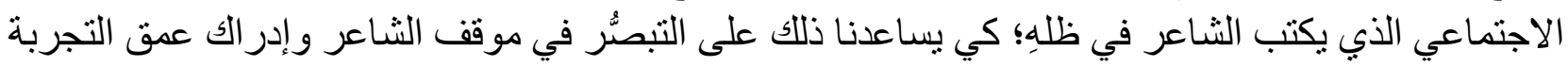
التي يقدمها، فقد عاش عبد العزيز عسير في ظل ظروف اجتماعية وسياسية سيئة ناتجة عن الاحتلال الأجنبي للعراق ورئاسة الدولة دن قبل شخصيات ظالمة، إذْ كان هذا ((هو الواقع الذي يعيش فئس في إطاره)) (و ادي،2000،صروناف).

فنجد في مجمو عتهِ (الثاشة ما بعد الورقة) أنَّ الشاعر قد تحدث على لسان الانسان في شخصيات مختلفة.

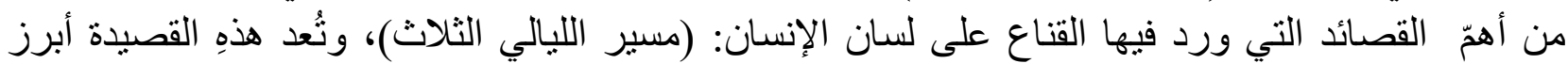
قصيدة قناع في ديوانه؛ فقد تقنع الشاعر فيها بشخصية أسطورية، الا وهي (زرقاء اليمامة) آخذاً من هذهِ

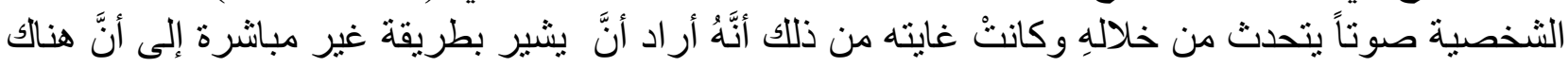

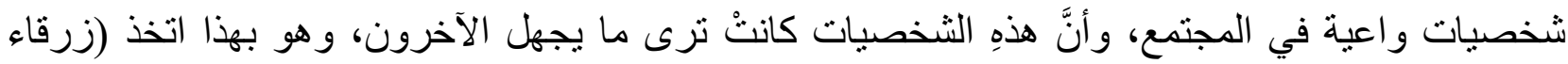
اليمامة) رمز اً للثخصية الو اعية وأنَّ هذهِ الثخصية هي التي ترى ما سيحصل في المستقبل أي: رؤية معنوية، فيقول:

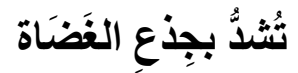

مرشحةً لتََََِّّ الحجَر

تصيحُ النساء:

\section{هي امرأةٌ .. كاذِبٌّ في الرجال}

\section{يقولُ حكيمُ اليمامة:}

ـ " إذا سار ركبُ الشجر اذاً فليغادر بخصرِِ ..

\section{•. جذعُ الغضى قبّل رمي الحجَر" (عسير، 2017،مج1: ص47)}

تبدأ هذهِ القصيدة التي وظف الثاعر فيها القناع بمشهد عن امرأة مربوطة على شجرة (الغضاة): وهي

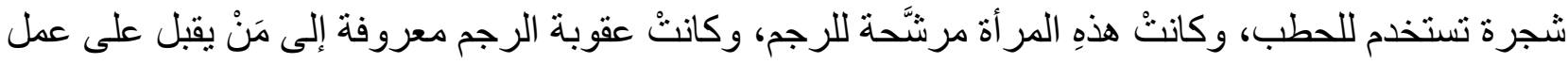

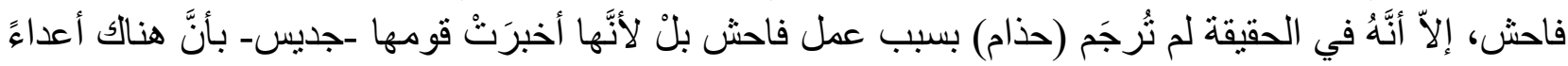

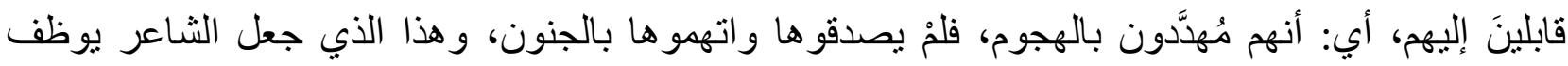




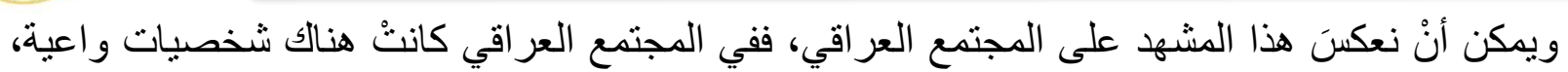

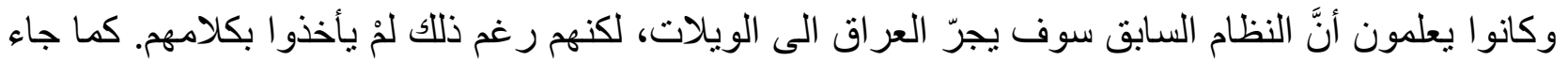
في قوله:

جديسُ ... فُمٌ واحدٌ يتصارخُ:

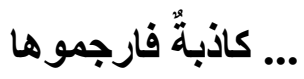

يصيح المذيع: ارجموها

فتطفأع عيناكلك ....

والثجراتُ اللواتي عبر البراري...

ومن خلفهنَّ السنَّيوف

\section{عبرنَ من البحرِ في المرةِ الثانية}

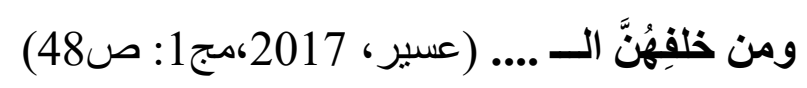

هنا يشير الثناعر إلى قبيلة (حذام) وكانتْ تلك القبيلة تُعى (جديسُ)، أما القبيلة المعادية المحتلة فهي

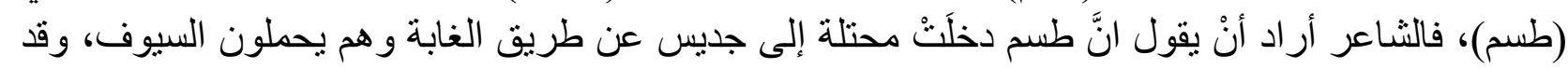

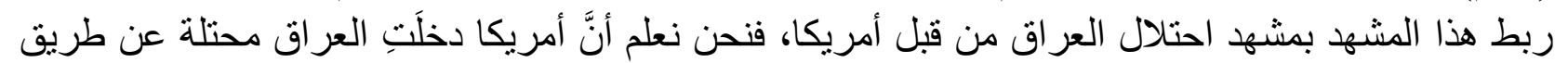

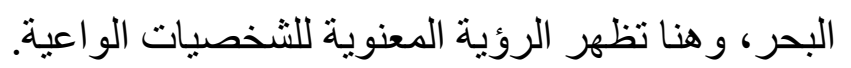

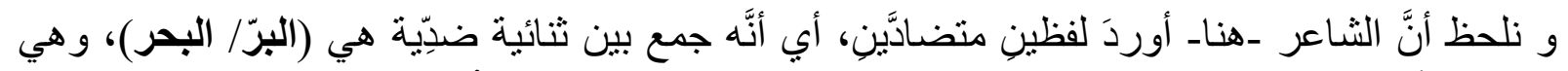

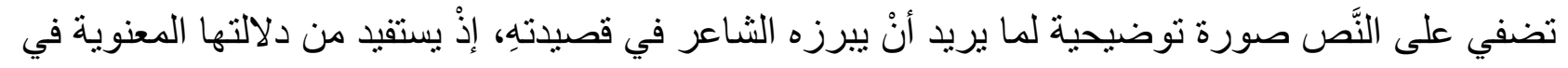

ومَنْ -غير عينيك- يبصرُ ما خلفهنَّ ؟

وفي كل منُعطفٍ تستقر المراصدُ...

شَاشَاتُ رادارَ ... صادقةٌ

تستثفتُّ البحار

ترانا على بُعدِ شهِِ

وحولٍ 


\title{
وتحسبُ أشجارَنا المستباحةً واحدةً واحده (عسير، 2017،مج1: ص48)
}

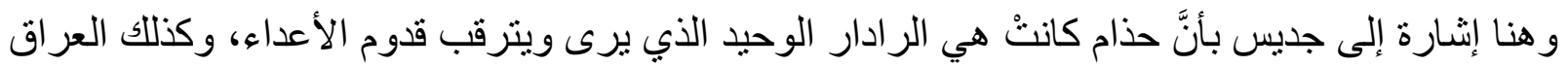

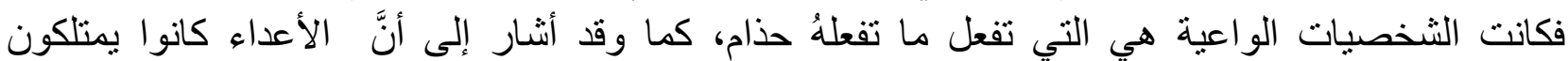

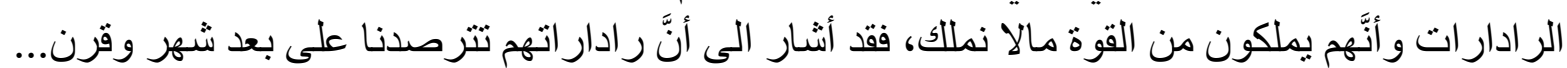

ويقول:

\author{
وعينُـ.......

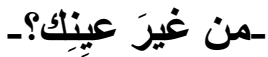 \\ مُذْ لِيلةِ الرجمِ...

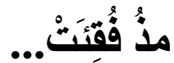 \\ وادلهمَّ مسير الليالي الثثلاث \\ غُشينا بأبصارنا \\ وصرنا على أرضنا... \\ وبين مضاربنا نحتمي بالثجر \\ ونصرف من طاقِة الظلِّ...

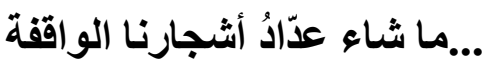 \\ وأشجارُهم ماشية!! (عسير ، 2017،مج1: ص48)
}

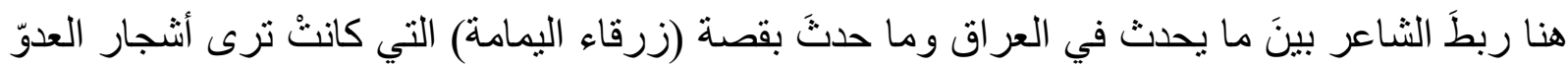

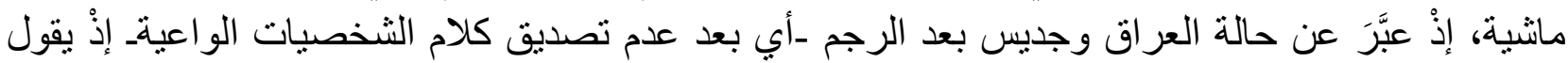

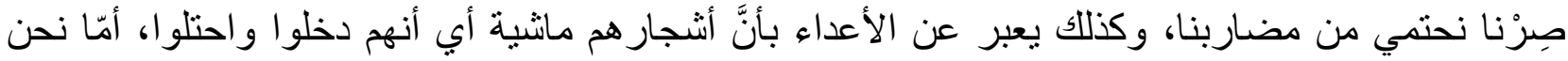

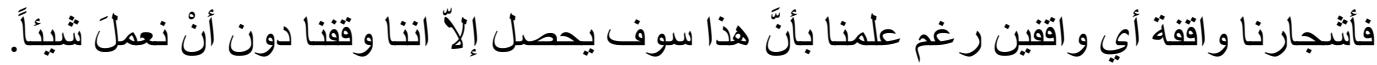

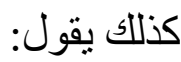

$$
\text { وصوتٍٍ... كأني به كان صوتَّكِ }
$$


أشجارُهم قادمة....

من البحرِ أثجارهم قادمة

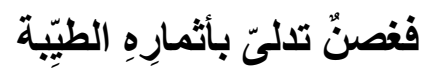

وغصنٌ تشظّى بأثمارِِ القاتلة

ولكن... جليسُ تكنِبُ عينيكِ (عسير، 2017،مج1: ص49)

هنا يشير إلى أنَّ الشخصيات الواعية تصرخ بأنَّ الأعداء سوف يدخلون العراق محتلين من البحر كما

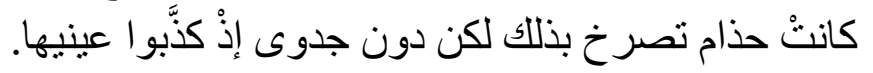

وقد أوردَ الثاعر الثنائيات الضدية في المقطعين السابقين وهي (واقفة/ ماثشية)، (تللى/ تشظى)، و عبْر

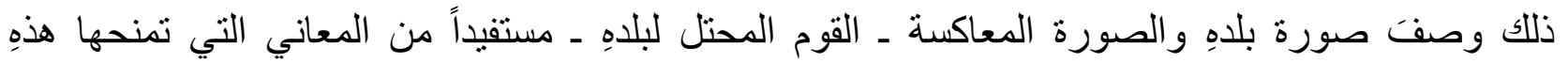

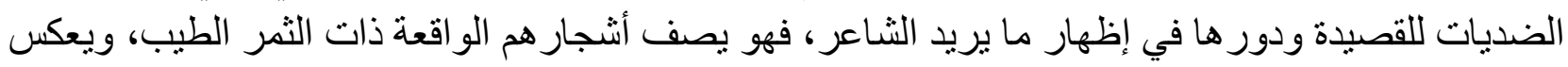
ضدها أثجار القوم المحتل الماثنية القاتلة.

ثنَّ يقول:

والغمضُ...

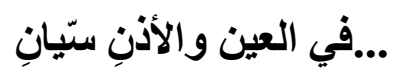

لو نزلت غابةُ البحرِ

شاطئنا المحتمي بالظلال (عسير، 2017،مج1: ص49)

هنا ربط الثاعر بين الذي لا يرى وبين الذي يرى ويتجاهل الحقيقة، فهُم عند الثاعر سيّان لا خلاف بينهما، فحذام أخبرتهم بالحقيقة ور غم معرفتهم أنَّها صلادقة كذَّبو ها.

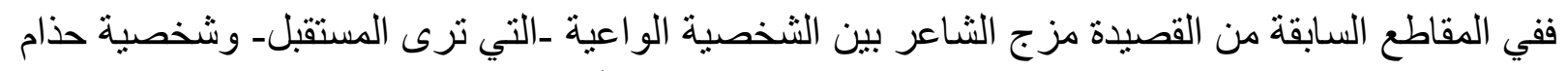

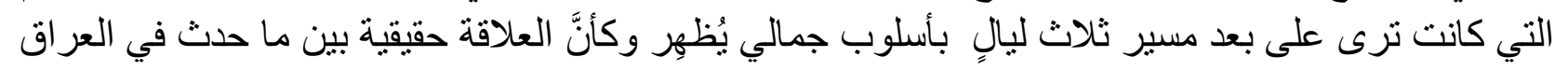
وجديس. ويقول:

تزور حذام طبيبَ العيون

وتسألُ عن قعر بنورةٍ و إطار

يضدّان لونَّ الحجارةِ عند القبيلة 
يقول طبيبُ العيون:

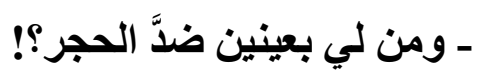

- إذذاً... أنت يا سيِّّي مِن جَديس

-دعيني لعينيكِ سيِّّني...

فما للطبيب وصرحَ الملوك؟

دعيني لعينيلِ....

عينالكِ ستُ على على أربعِ

وعشرينَ...

و الشبكية مسوّدةٌ كالظلام

ولمّا انتهنتُ عدساتُ الطبيب

من الكثَفِ مرّتَّ عيونُ حذامِ

بخارطةٍ للوطن

معلقةٍ خِلفَ كرسيِّهِ المستدير

وتشتبأُ النظرتان

ومثل العبيبين يلتقيان

تقاطعتِ الزرقةُ...

الوهجُ في زرقةِة العين...

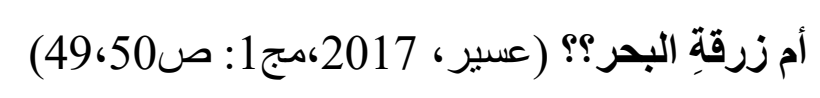

يشير إلى أنَّ حذام تزور طبيب العيون من أجل الحصول على نظارة تقوّي بها بصرها، وقد دار بينهر

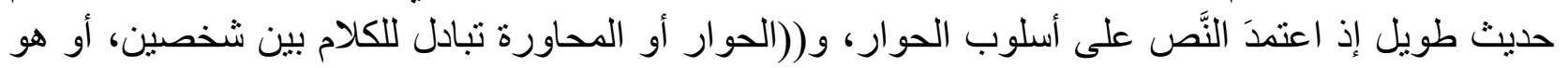

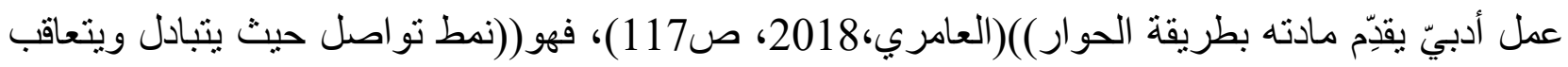

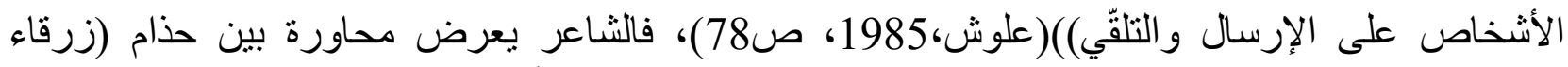

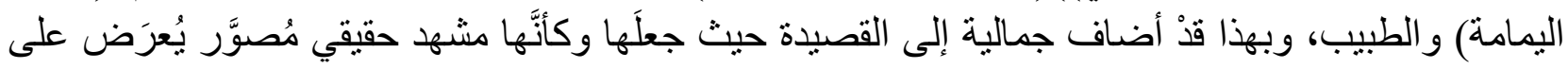

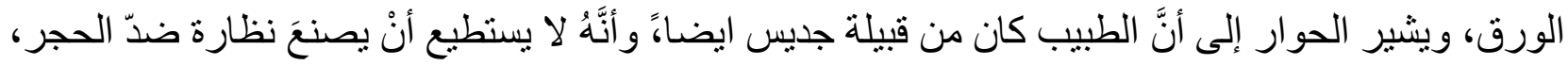

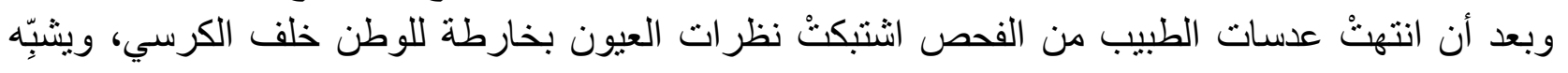


الثناعر اشتباك النظر ات بين الخارطة وحذام بتثابك حبيبين يلتقيان بعد الفراق كناية على حبّ حذام إلى قبيلتها

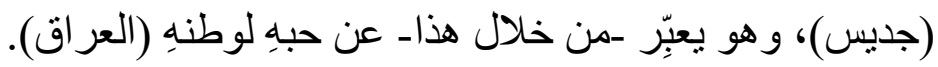

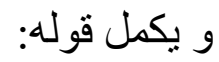

\section{قِّا أغمضتْ عينها}

ثم قالت حذام:

ألا... قنّ لقومكَ... دكتور...

إنَّي أرى خضرةَ البحرِ حتى السواد

تراودُ أرضنَ اليمامةِ عن نفسها!! (عسير، 2017،مج1: صكئ 50، 51)

هنا يكمل الثناعر المشهد الحواريّ السابق بين حذام والطبيب، فإنَّ حذام من خلال ذللكَ تحاول أنْ تُظهِِر

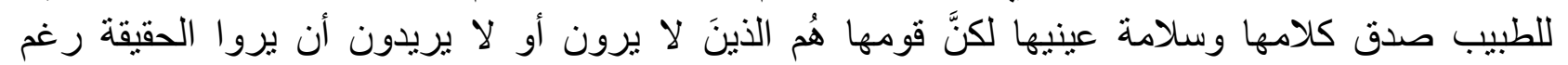
وضوحها.

وفي هذا النَّص أشتارَ الى أرض السواد (العراق) عبْر الإشارة الى قبيلة جديس، وتطلب حذام من الطيب

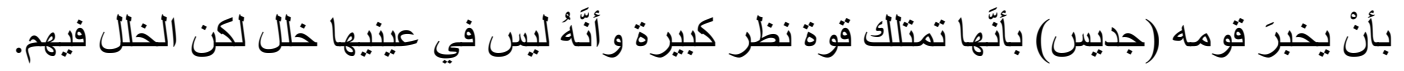

ومما تقدم يمكن القول انَّ الثاعر جعل من حذام التي هي القناع للشخصيات الو اعبة رمز اً للرؤية المستقبلية

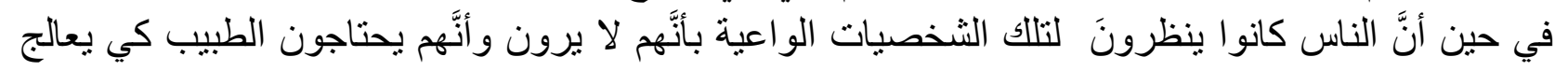

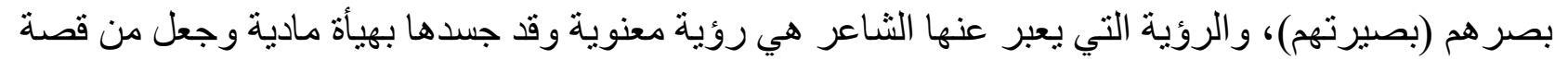

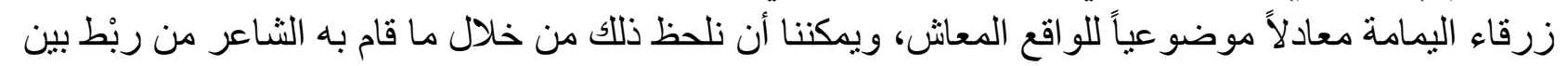

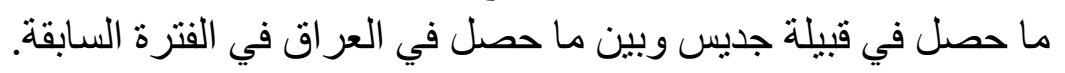
ثم يكمل الثاعر بقولها:

\section{وعند نزول حذامِ ببابِ العيادةٍ}

قد شاهد الناسن يوماً

\section{عجوزاً على عينها قعرُ قنينةٍِ...}

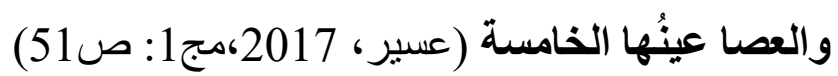

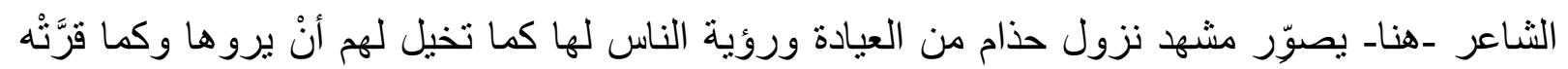

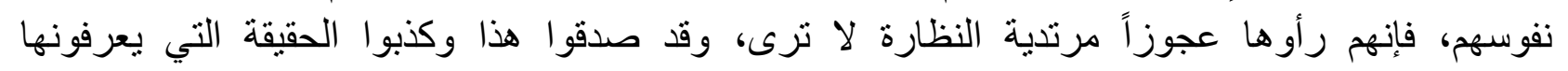
وتجاهلو ها. 


\section{مجلة لارك للفلسفة واللسدانيات و العلوم الاجتماعية المجلد (2) العدد (41) السذة (2021) بحوث اللغة العربية}

تززور حذام بلادَ المغتِّنَ...

وجهاً لوجهٍ

يطالعُها المطربُ الشيخُ....

كان يصيح

بذاتََ المقامِ "الحجاز " الجميل:

بلادي وإن جارته عليّ عزيـــــــة

وأهلِي وإنْ شحّــــوا علَيَّ كــــرامُ

وقلبي على الصدعات صار مُعلَّمَاً

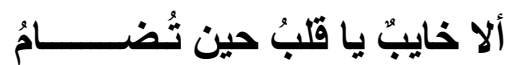

بلادي...

وأهلي...

وقابي....

بلادي... بلادي... بلادي

بلادُك!!!!

بلادوََ يـا أيَّها المطربُ الشيخُ

يا خايبَ القلب

كم أنتمُ طيبون!!!

ولا عيب فيكم

سوى أنَّكم لا ترون الشجر

ولا ما وراءَ الثجر

ولا ما أمسامَ الشجر

هي الارضن مرهونة في البنوك 
ما جودُ أهِلَكَ حين ثُباع الغصون؟!

ويستصرخُ المطربُ الشيخ:

-أرجوك سيدتي...

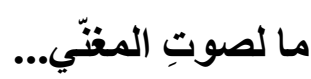

وهذا الحديثَ الخطير؟!

أنا اليوم غنتَّنُ

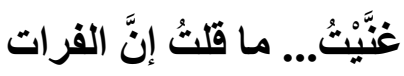

يصبُّ ببحر اليمامةِ...

ما قَلْتُ إنَّ جديس العراق

تُماهي عراقَ جديس! (عسير، 2017،مج1: ص151، 52، 53)

يشثير الثـاعر إلى أنَّ حذام تزور شار ع المغنِينَ بنفسها و هناك سمعتْ شيخ المغنين (أي كبير هم) وهو بغنتي

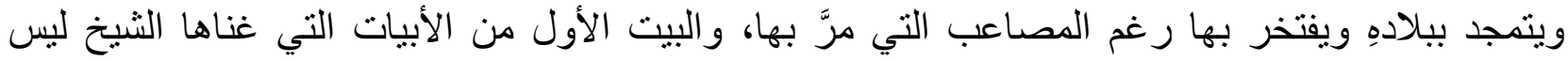
للثـاعر نفسه، انَّما ضمَّنَه الثـاعر في قصيدتهِه. و التضمين عند البلاغيين بعني((أخذ قول شاعر وبناء شعره أو

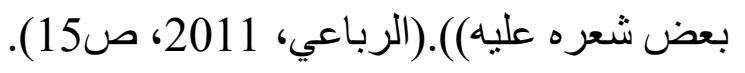

كما أنَّ هنالك اشـارةً إلى أنَّ حذام قدْ ردَّتْ على المطرب باستفهام إنكاري، وهذا النوع من الاستفهام

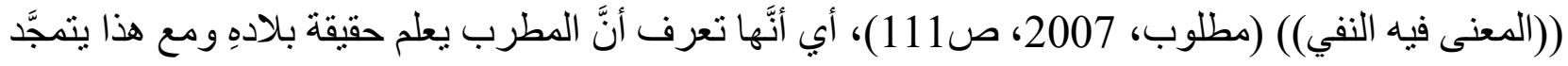

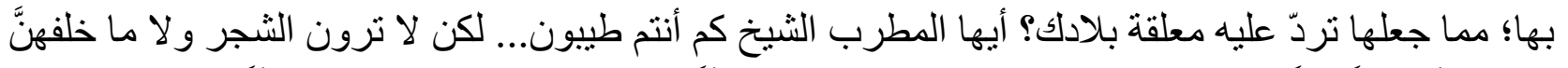
ولا ما أمامهنَّ، إنَّكم تتظاهرون الجهل عن البصر رغم أنَّكم ترون ذللك بكل وضوح و أنَّكم على علم بما

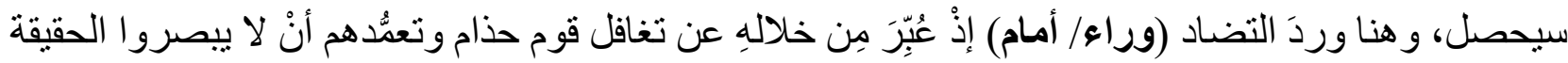

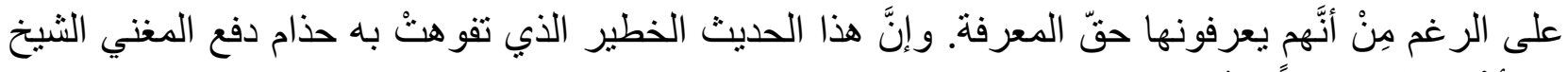

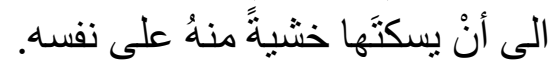
ثنَّمَ يكمل المشَهَدْ بقوله:

وعند انسحاب حذام

مهربةًَ من بلادِ المُغّنينَ

كان يطالعُها المطربُ الطقلُ... 


$$
\begin{aligned}
& \text { والمطربُ الطقلُ } \\
& \text { ليس يجُيد المقام "البيات" } \\
& \text { ولكن يصيح... } \\
& \text { على درجات القرارِ الكسير: } \\
& \text { "أضاعوني وأيَّ فتى أضاعوا ليوم كريهةً" فمن المغنّي؟؟ } \\
& \text { وكم غنّيُُهم برخيـم صوتي فردوا النغمتين لصغرِ سنّي (عسير، 2017،مج1: ص53) }
\end{aligned}
$$

و عند خروج حذام من بلاد المغنيّنَ صادفتِ المطرب الطفل يغنّي، و هنا مفارقة بين ما غنّاءُ المطرب الثنيخ

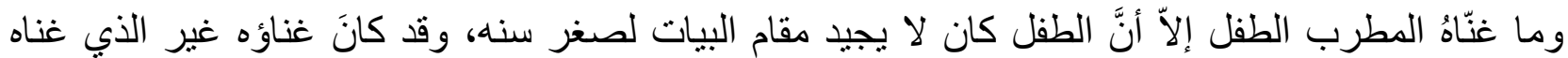

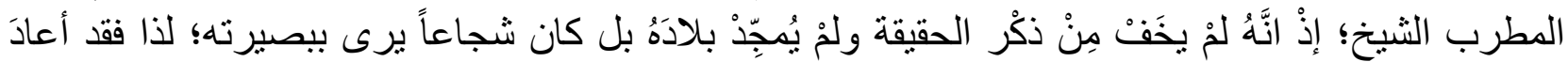

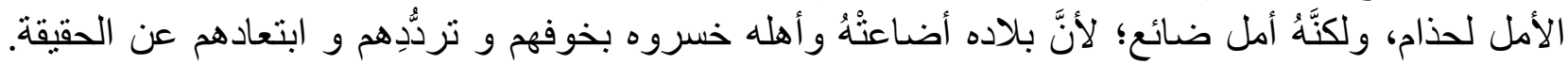

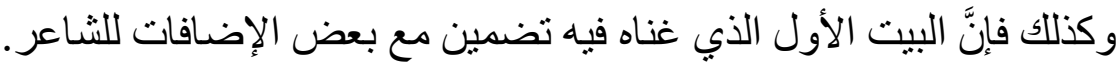

تجوبُ حذام الشوارعَ

تأتي الى شارعِ مُفْعِ بالرجال

الحناجرُ تعوي وتصهُلُْ، واللافتات

كما البحرُ حين يكيلُ الشتائمَ للجرفِ....

تلذخلُ وسنط الزّحام

تحدّق في غابِة اللافتتات

وتقرأ ما كان خلقَ الشجر

فتحمل فانوسنها في النهار

وتبحثُ عن قامةِ....

لم تزل بعُ منُتَصبِة

يباغتها القرد... يُومِئ: 


\section{إني استعدثُ}

-وعينيلك-

\section{كاملَ أطر افيَ الأربعة}

\section{وأبناء عمي عادوا الى ققزات الغصون (عسير، 2017،مج1: ص54، 55)}

هنا يشير الثناعر أنَّ حذام تدخل إلى شار ع مُفعَم بالرجال، وهنا تتماهى قبيلة جديس في العر اق تماماً، فهو

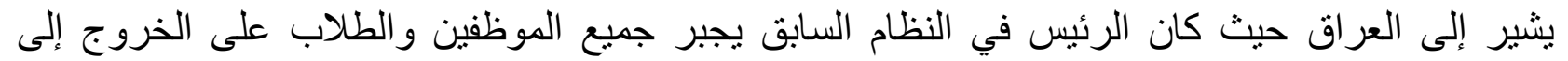
التظاهر إثارة الى مسيرة السخرة، وكانته هذهِ المظاهرة يُجبَر فيها الناس على نتأييد صدام حسين ضد فئ أمريكا،

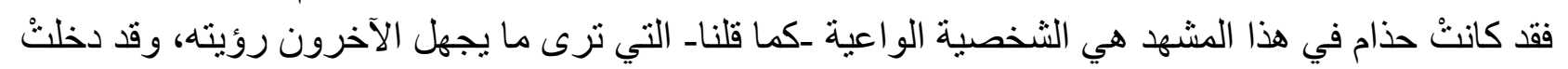

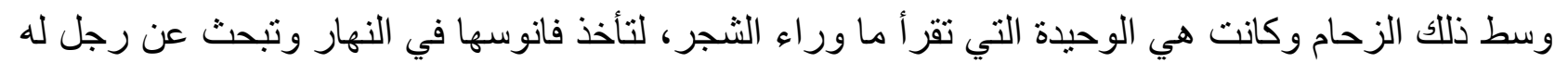
قامة لمْ تتحني للنظام، وهنا أحال الثاعر إلى الفيلسوف الذي شاب فيه بعض الثض الملامح الأسطورية (ديوجين الكلبي) اليوناني الذي كان بيحث عن إنسان وكان يحمل مصباحاً في النهار.

ثم يصور الثناعر حال تللك الثخصية في ذلك التظاهر بقولهِ (يباغتها) أي يهاجمها القرد، و القرد في حقيقتهِ لا يتكلم لكن يومئ، و هنا أيضاً قناع للناس في تلك الفترة، أي أنَّ النظام السابق جعل من أغلب الناس قروداً

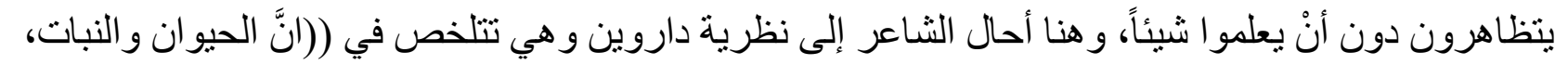

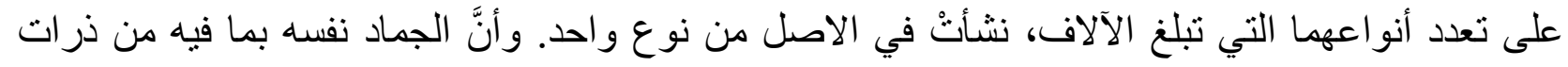

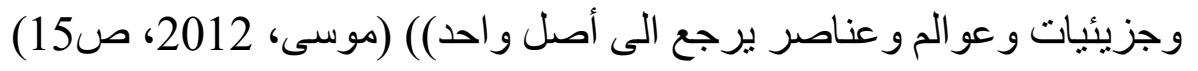

فإنَّ الثاعر أثنار إلى أنَّ القرد والانسان من فصيلة واحدة وأنَّ القرد في هذهِ القصيدة نزلَ من أعلى فُ ألى

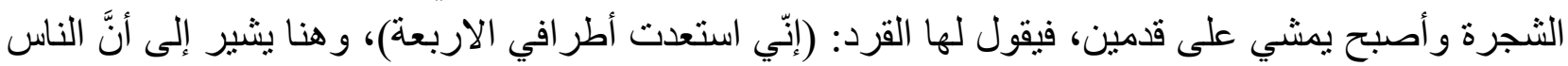
الذين يؤمنونَ بالمظاهرة ـمساندة للنظام- رجعوا إلى أصلهم كونهم قروداً لا يفقهون شيئًاً. ثم يقول:

\section{وأمّا عقال اليمامة}

فإنَّ أيادي الرجال

ستحميهِ من حدَّة الرقص

أنتِ اطمئنّي إلى الرقصِ

أنَّى تميلٌ الرؤوس

سيسقطُ...

من تحت كوفيةِ المرعِ شيعُ 
وييقى العقال

فتبكي اليمامة... تبكي

وتبكي...

\section{وتمستح دمعاتِها... (عسير، 2017،مج1: ص555)}

يشير ـهنا- إلى العقال الذي تحرص اليمامة على عدم سقوطِه لارتباطهِ بالعقل، ولكنْ ينَّضحح لها أنَّ هذا

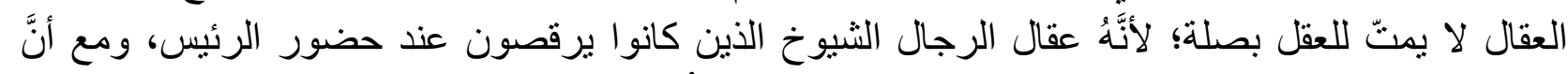

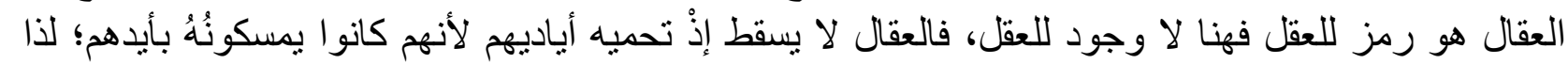

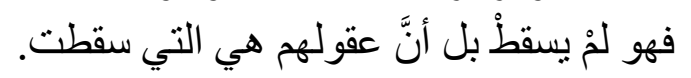

ويقول:

ثم تتهضُ تعطي الرجالَ القفا

وتفتُشُ عن طقلةِ أو طُفيّل

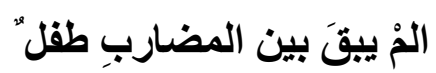

يرى ملكاً عارياً؟

تعال أيا ولاي

تعالَ... - ت

فأنت الوحيدُ الذي قد يصدقُني لو أقول:

أبوك يبيعُ الشجر

ليشترِيَ امرأةً غير أمِّكَ...

انتَّ الوحيدُ القمينُ بثثيي...

بثذيي الذي أتعبَ امرأةً عانساً...

وهي تكتبُ فيه اللبن

تعال أيا ولاي (عسير، 2017،مج1: ص55، 565)

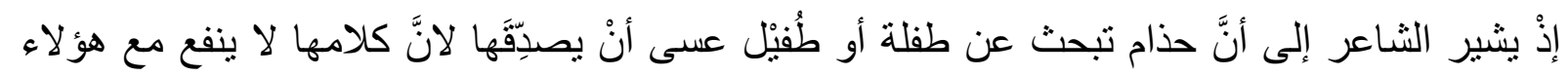

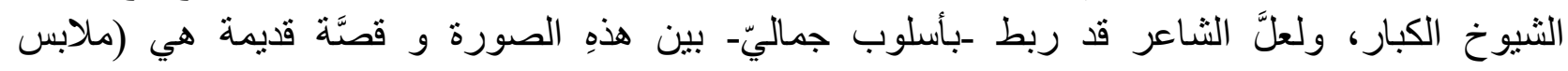




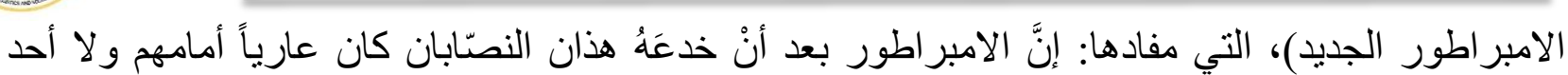

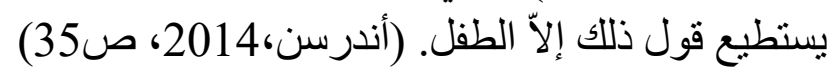

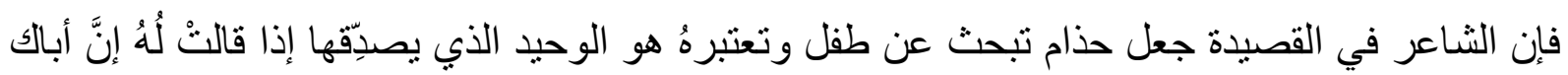

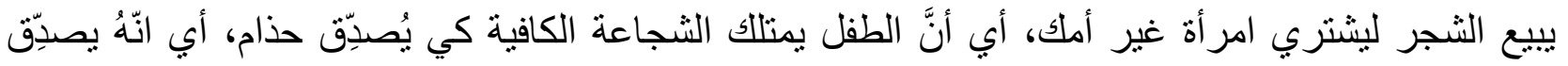

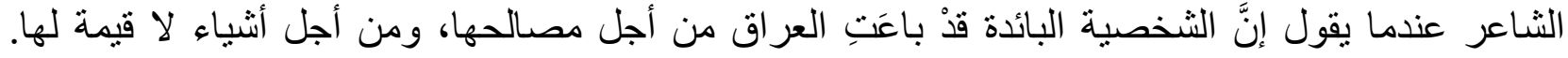

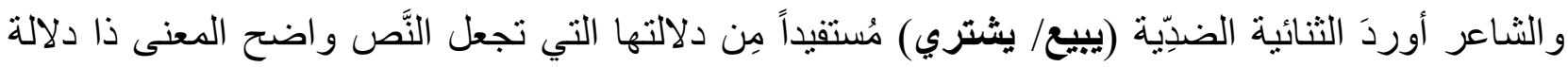
موحية.

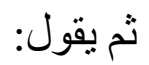

تضمُ حذام الوليدَ المُشرَّد....

والكامِراتُ التي اجتمعَتْ كي توثِّقَ

فوراً تباعدنَ...

حتى اختفينَ وراءَ الثجر

على إثْرِ صرختِها:

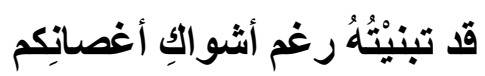

وصُبّرُ غاباتِكم ما يزال

$$
\text { يحاصر عيني... (عسير، 2017،مج1: ص56) }
$$

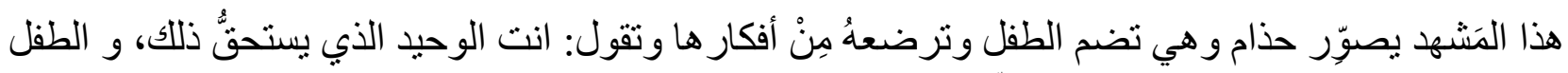

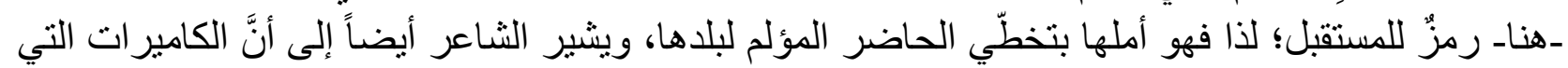

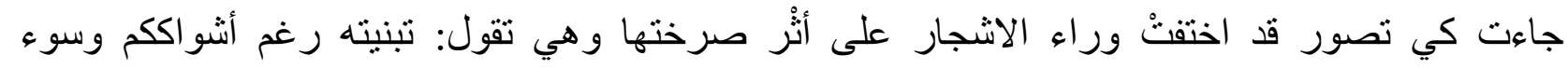
تصر فاتكم.

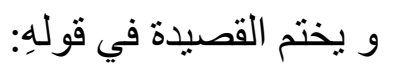

احتضنْتُ الصغيرَ المشردَ

أمنحُح قامتَّهُ الإنتصاب

وأُرضعُه إرثَّ عينيَّ

أملأُ عينيهِ بالبُعِدِ والنورِ 


\section{حتى يرى الغابةً القادمةة(عسير، 2017،مج1: ص57)}

و هنا أكَّتتُ (حذام) أنها سوف تمنح الطفل قامة الانتصاب وترضعه إرث عينيها، أي تجعله يرى ما لا يروه حتى يرى الغابة القادمة، فهذِ القصيدة تنبأ بغابة أخرى قادمة لهم وهي (احتلال العراق)، وقد تحقق ذلك بالفعل.

إنَّ الثاعر اتخذ من شخصية زرقاء اليمامة (حذام) صوتاً له اختفى وراءه و عبَّر عن غايتهِه التي جعلتُهُ

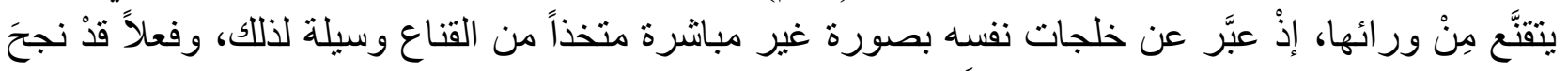

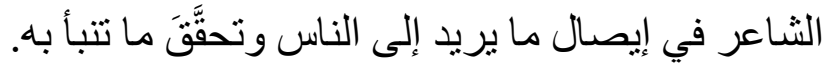

إنَّ هذهِ القصيدة قُر أتْ في حفل اتحاد الأدباء سنة 1991م؛ ولسوء الحظ كان أحد المسؤولين في الدولة من

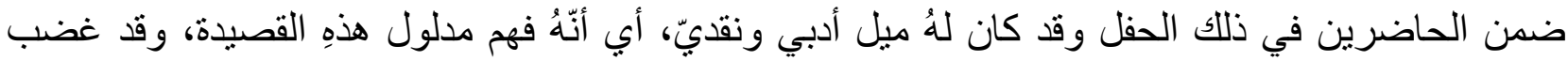

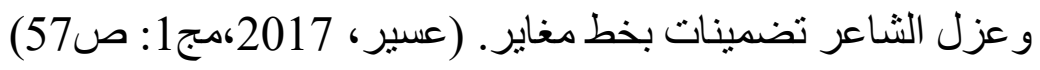

إنَّ هذهِ القصيدة من كتابات الثـاعر سنة 1991م، ومما لا يخفى عن القارئ أنَّ احتلال العراق من قبَّل

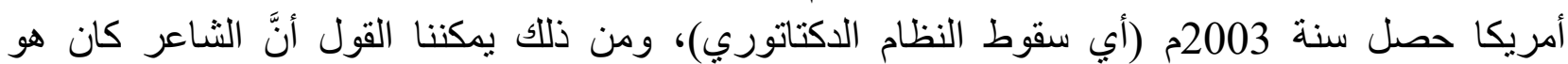

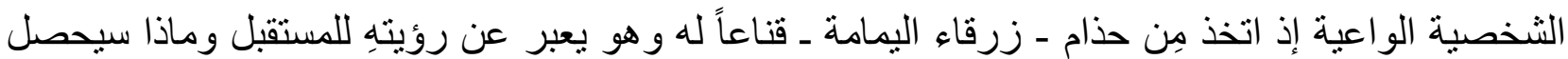
للعر اق وفعلاً تحقَّقَ ذلك. الكَ.

كما لابدَّ مِن الإشارة إلى أنَّ أسلوب الثاعر في هذهِ القصيدة التي تعتبر من قصائد التوعية للناس، هو

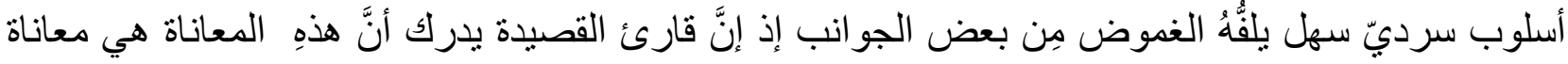

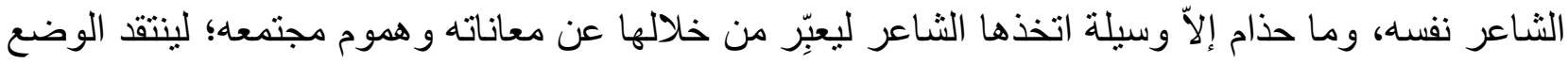
السياسي السائد في العر اق وسوء الحاكم الذي فضل مصالحهه على مصالح شعبه. ونجد الثاعر متقنعاً في مقطع من قصيدة أخرى عنو انها (فُبَّعة الارغِفة) إذْ يقول:

دخلتُ خباهَه المشُودَ بالظطلماتِ

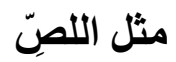

أكتمُ ضحكتي بأصابعي العثرِ

وغادرَ عاصرُ الخمر

وغادزَ بعده رأسهُ

له طبقُّ... به خبزٌ تحطٌ عليه

أجناسُّ من الطيرِ (عسير، 2017،مج1: ص57) 
فقد تقنع الثاعر في هذا المقطع من القصيدة بشخصية تأريخيَّة و دينيَّة هي شخصية النبي يوسف (عليه

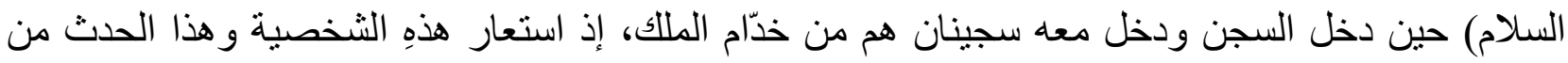

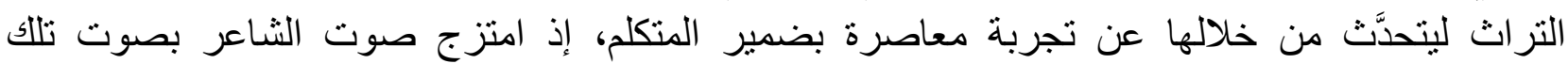

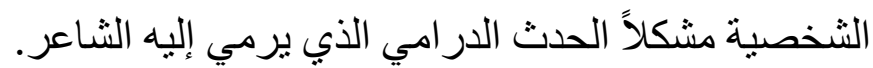

وأر اد الثناعر من خلال ذلك أنْ يضع دلالات جديدة فقد جعل صوت الماضي يُدغَم في صوت الحاضر فأنتجا تجربة شعرية جديدة تتحدث عن سمات العصر و الظلم فيه.

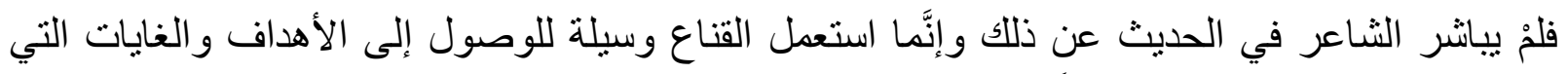

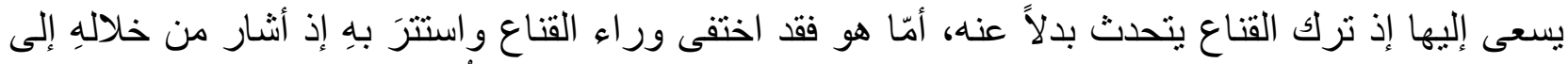

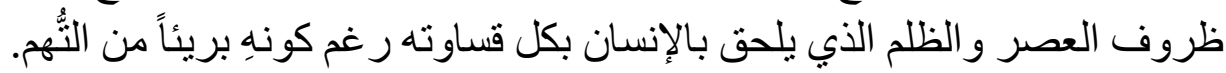
كما نلمح القناع في مقطع من قصيدة (بصمة قدم ... على رمال البصرة الأولى) إذ يقول: يدي لم ترتفعْ... وأنا أوَدَّي في الطريق للك التحيةَ....

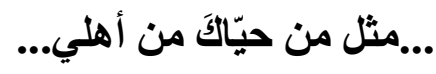
فما أنا بالحفيد... ولا المريد... ولا النجيّ المستجير...

وإنما... أنا وارث الثمع الذي في جيبه نصفت لشمعتَكَ المنيرةِ للضيوفِ

إذا أتى ضيفي... بوازرةٍ من الظلمات بين الصعب والسهلِ وبين الكيلِ و الكيلِ

وبين الكفَّ إذ تبقي على الأنساقِ... أو تنساقُ للميلِ وبين الظلم والعدل

سأطفى نورَ "بيت المال" حتى يخرجَ اللصّّان مِن ليلي ومِن شٍِّ بسيفك سوف أنظرُ كي أرى الأثياء من حولي

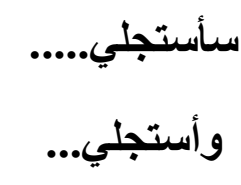

تُرى...ماذا سأبصرُ...؟ (عسير، 2017،مج1: ص66 ، 67) 
في هذهِ القصيدة يلجأ الثـاعر إلى التقنّع، وقد استعمل القناع بوصفه وسيلة فنية للتعبير غير المباثنر عمّا

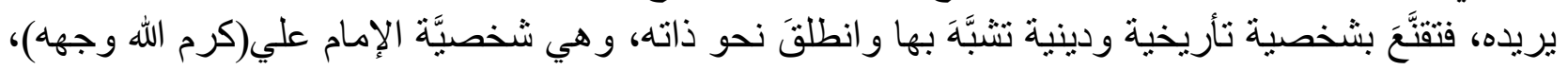
وتحديداً في عدالتهِ، إذ كان لا يستخدم شمعة بيت المال للأغر اض الثخصية، وقضية الثمعة التي أطفأها الإمام علي (كرم الله وجهه) شهيرة في التأريخ عندما جاء إليهِ أحد الأعر اب في قضية شخصية فقام الإمام (كرم الله وجهه) بإطفاء الثمعة؛ لأنه يستخدمها في الأمور التي تخص الناس وليس في المسائل الثخصية. وهنا وردَت المتضادات في قولِِ(الصعب/السهل)، (الظلم/العدل) وعبَّرَتْ عن عظمة الموقف وحقبقتهِ و أهميتهِ

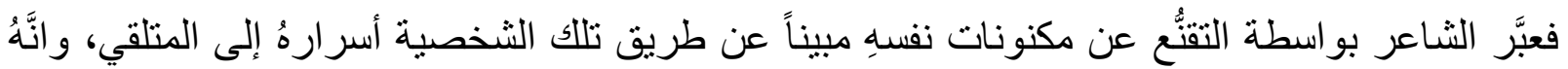
اتخذ من سيف الإمام (عليه السلام) مقياساً للحق ضدّ الباطل، فالثاعر من خلال القناع ينقل للمتلقي ما ينطوي نفسه من الحب و العدالة والإنصاف وما يشيع في المجتمع من ظلم و إجحاف. وأيضاً يتقنَّع الثـاعر في مقطع من قصبدة أخرى و هي (الكنغر) إذْ يقول: والسقوفُ الثثلاثةُّ للرعبِ مُطبِّةٌ كالوصيد

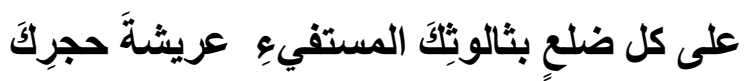

من وهج "يوم النيازلِِ"

$$
\text { ثُ تطامنتَّْ... قَلت }
$$

- ساوي الى مصحفٍ

$$
\text { غادرتْهُ على الرفتِّ... (عسبر، 2017،مج1: ص66 ، 67) }
$$

ففي هذا المقطع يتخذ الثاعر من أصحاب الكهف قناعاً للتعبير عن الهلع والخوف، وأصحاب الكهف آووا إلى الكهفِ في الجبل خوفاً من الحاكم آنذاك، وكان ملجؤه هم الوحيد هو الكهف...

و عندما قال الثاعر (سآوى إلى مصحف...) فقد حوَّر الصورة وشكَّل منها شيئًاً من لوازم القناع وهو

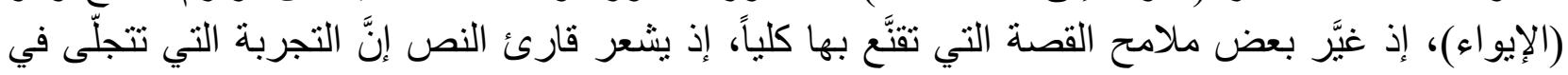
النص هي تجربة الثاعر وليستُ تجربة أهل الكهف، وفي الحقيقة لا تمثل تجربة أهل الكهف سوى سوى وسيلة للتعبير عما أر اده الثاعر في حالة خوف يستطرد في نفسهِ إذْ يندفع نحو النصّ ليشكل معهُ حالة من الإربالك

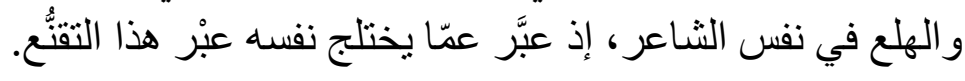

وكذلك نلحظ الثاعر متقنعاً بمقطع من قصبدة أخرى في الديوان وهي (انكسار ات الأفياء)، إذْ يقول: الفيعُ بالقيعِ

والغصنُ بالغصنِ 


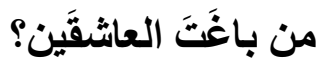

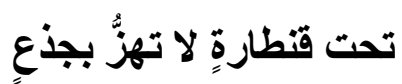

\section{الى عذرةِ الاختضاب}

\section{كي تُساقِطِ بالرَّطَبِ المُستطاب(عسير، 2017،مج1: ص198)}

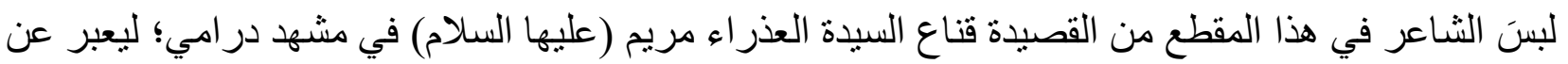

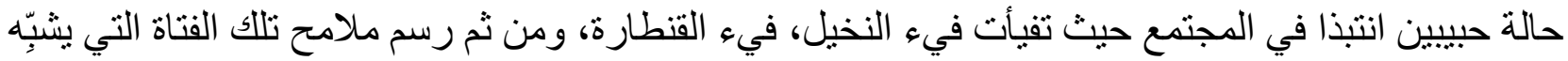

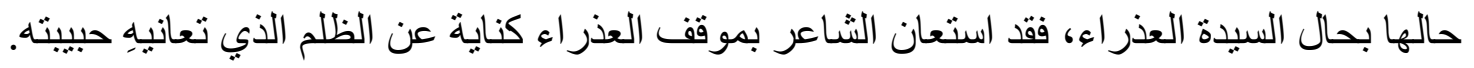

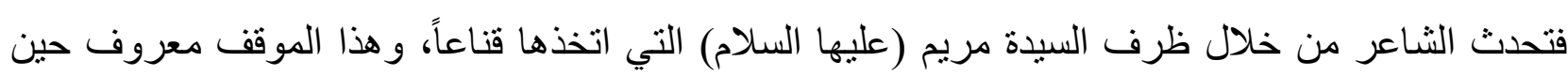

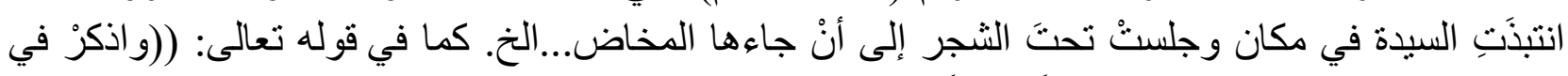

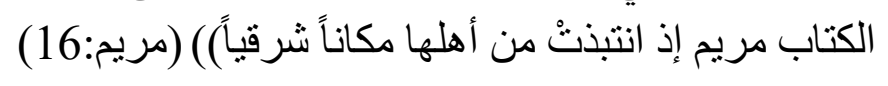

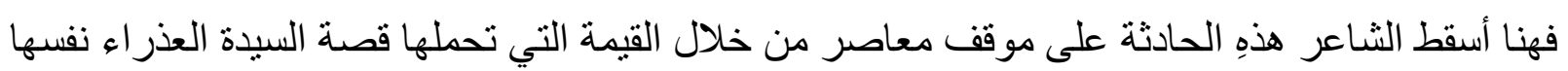

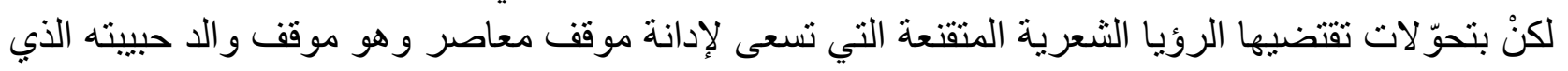

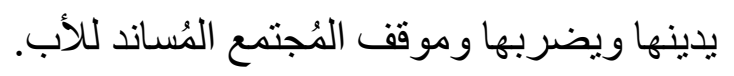
وكذلك في قصيدة (الحوت) نجد الثاعر مثقنعاً في قولهِ:

\section{يوم غادرتُ أحشاءكَ المظلمة} سقطنْ مقلتايَ على كبٍٍ

\section{لامعِ زيتُها}

\section{كنتَّ من يومها...}

كنتَّ... نبعَ الزيوتِ الوحيد

لبنادقها

\section{و الاليلَ الوحيد}

\section{لبوارجنا العاطبة (عسير، 2017،مج1: ص181)}

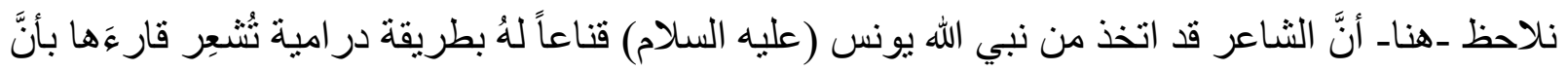

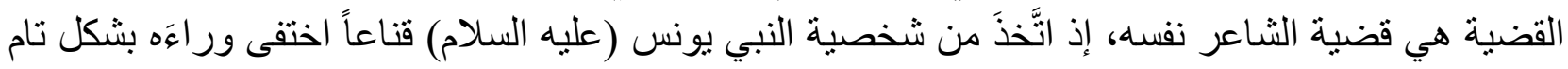

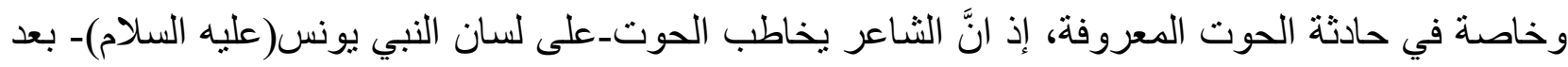

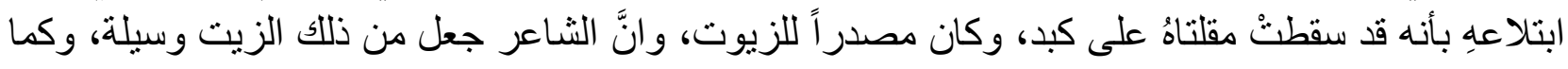




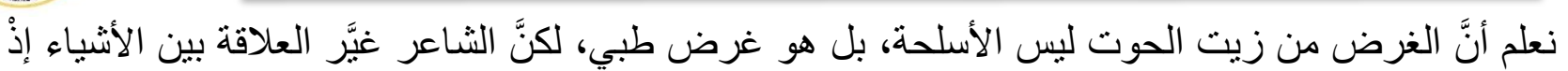

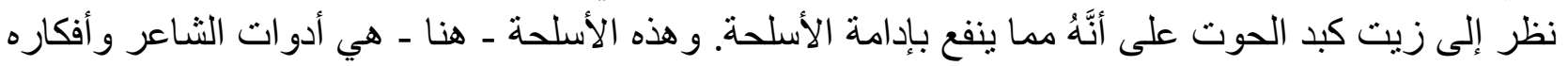

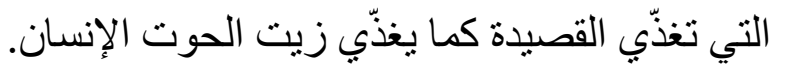

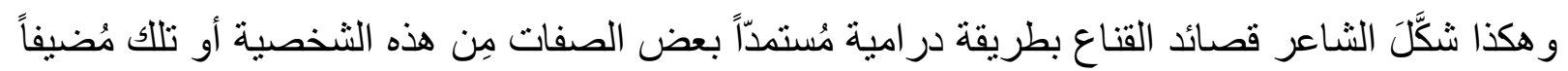

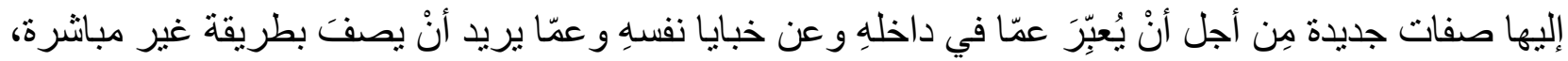

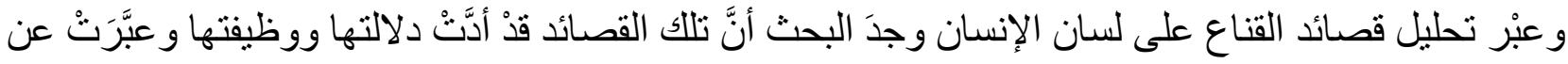
مكنونات الثناعر.

$* * * * * *$

\section{المبحث الثاني \\ القتاع على لسان الحيوان}

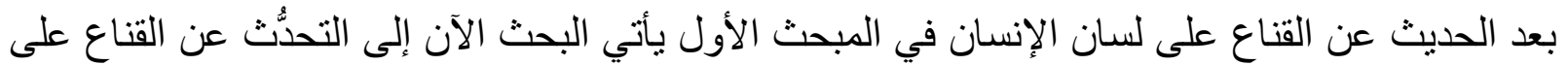

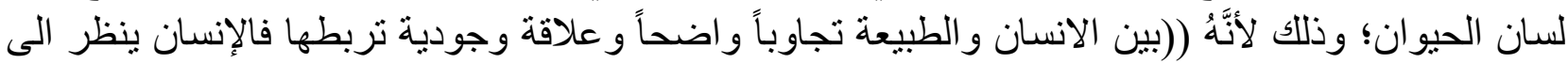

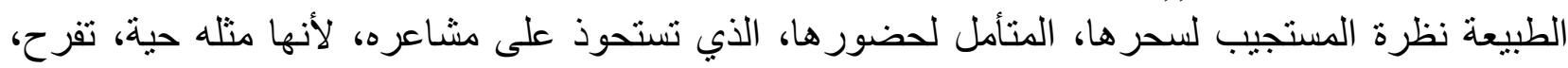

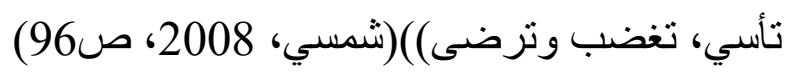

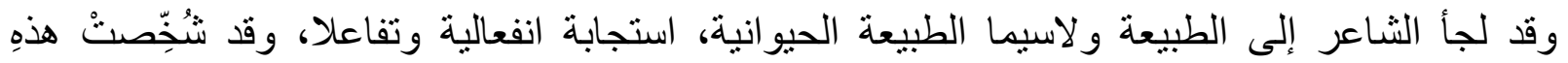

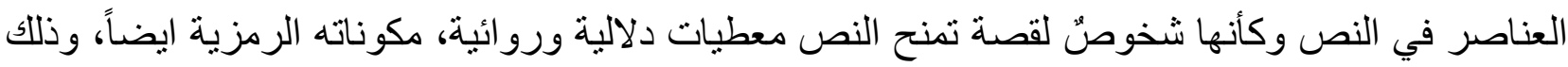

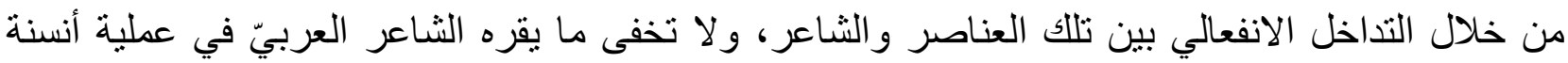

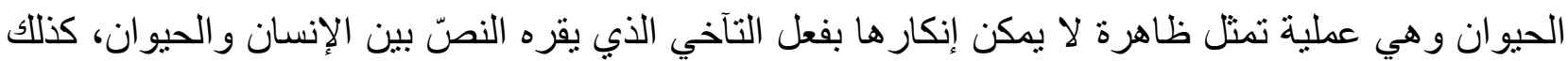

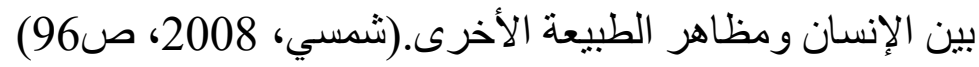

ولعل أقدم أنماط القناع استعمالاً هو ما ارتبط بالتشخيصات التناريخية، لكن الثناعر قد لجأ إلى الحيوان

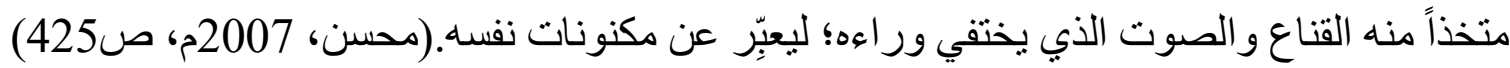

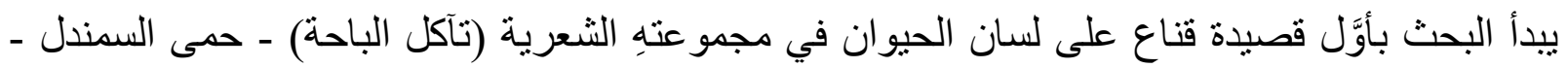

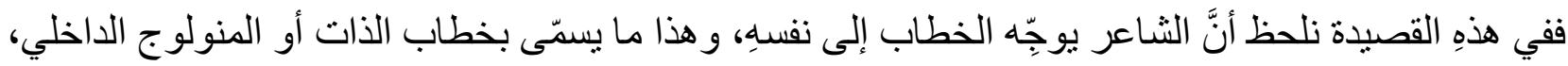
و المونولوج بشكل عام ((يشكل محاولة للخروج من أسر الداخل نحو الخارج من الأنا إلى الثخص الثص الآخر.

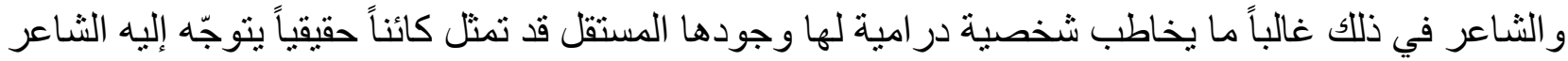
بالخطاب، أو يكون بمثابة رمز مجسد لحقيقة معنوية أو مجردة كالثورة، أو القضية، أو الحزن أو ماثنابه

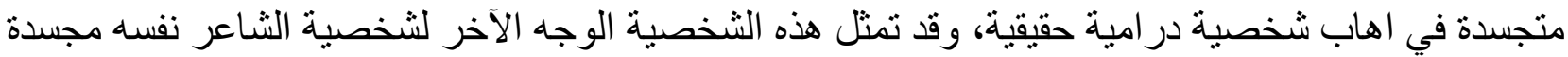

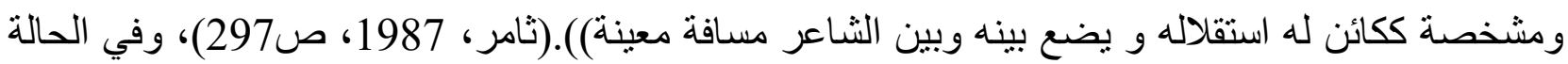

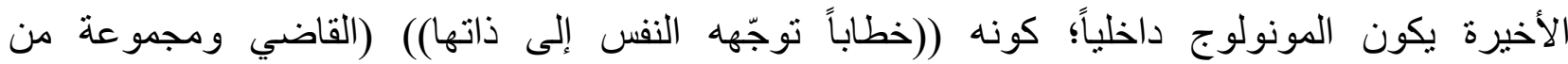

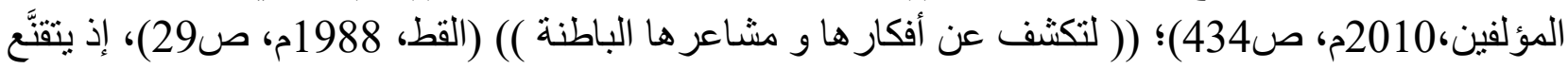




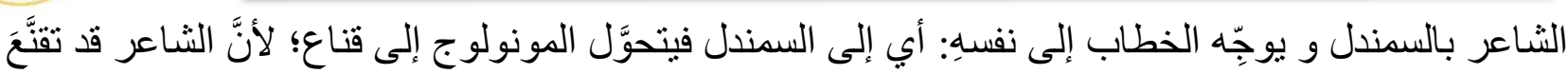
بالسمندل بصورة تامَّة، فهو يقول:

\author{
يُبِاغِتُكَ البردُ.... \\ مِحرارُكَّ الآن يقرأ عشراً \\ ويحمومُ موقِدَكَ المتهافتُُ ذارِينةٌ للستّخام \\ تنوَّرَتَ عبْرِ رمادِكِ برقَ نهارِ مطير \\ بهله قد تأبِّطْتَ ناراً \\ وشيئاً شبيهاً بعينيك \\ يقدِحُ... يقدَحُ... يلتهبُ الخِدرُ \\ تقتحمُ الخدرَ قامتكَّ الحامية.... (عسير، 2017،مج1: ص82)
}

بدأ القصيدة بحوار ذاتي وهو يتقنع بحيوان صغير يدعى السمندل: وهو حيوان صغير يشبه العظاية

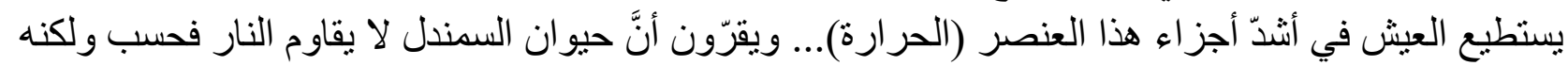

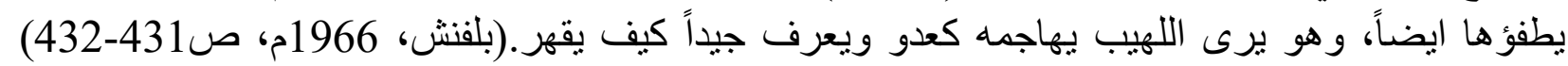

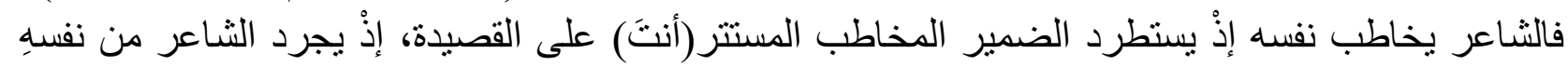

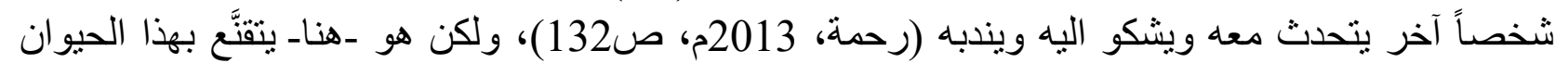

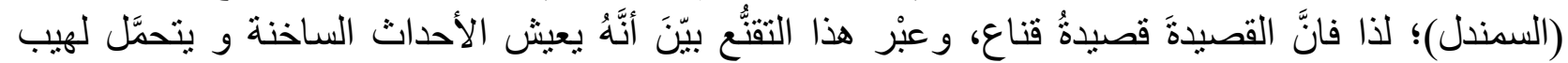

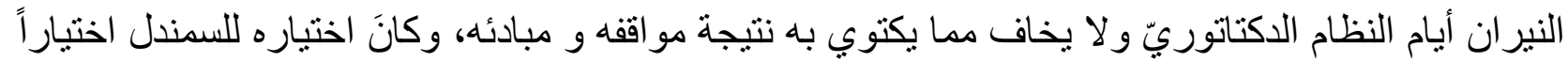

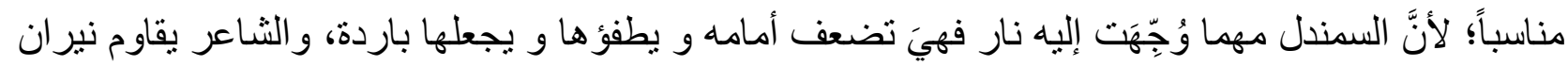
(أفعال) النظام الدكتوتاريّ بصبره و إر ادته. فهو يقول:

تذكرتَ مجدَ اشتعالِكَّ ... إذْ تصطلي زرقةََ النتارِ فجراً

وتندسُ في حمرةِ الجمرِ ظهراً

وليلاً... تُنَادي رجالَ المطافئ :

عودوا... ولا تقلقوا على جسدٍ يعثقُ اللهبَ الأبديَّ

ويمتهِنُ الاحتراق

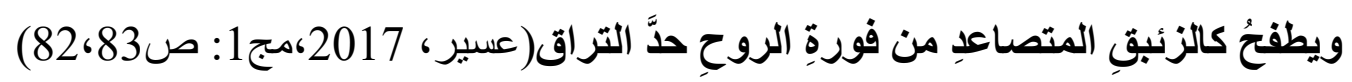




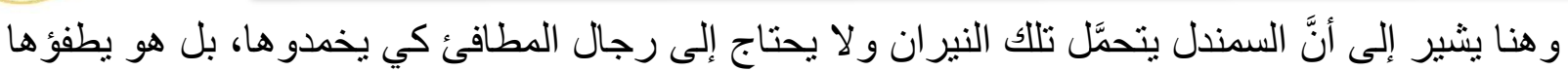

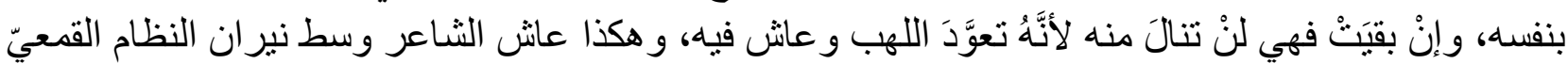

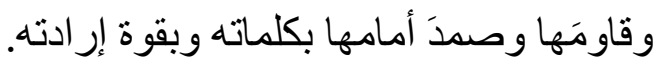

ومن القصائد الأخرى التي يتحدث فيها الثاعر متقنعاً على لسان الحيوان هي (الذئب) إذّ يقول:

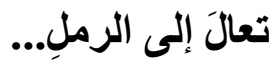

....أوجعََ اللوحُ في غابةِ الكلمات

\section{تثابُبُ حرفٍ وحرف}

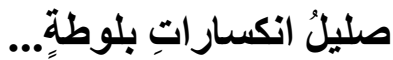

...تثقاطعُ أفياؤُها وظلالَ الصنوبرِ

$$
\text { فيءُ الصنوبرِ... (عسير، 2017،مج1: ص103) }
$$

في هذهِ القصيدة يتقنَّع الثناعر بصوت الذئب ويتخذ من هذا الصوت الوسيلة ليصل إلى غايتِهِ التي تقنَّعَ منْ

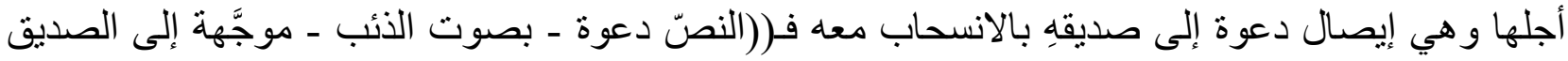

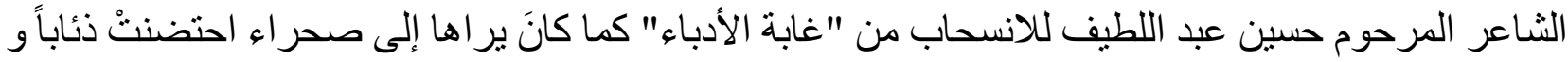

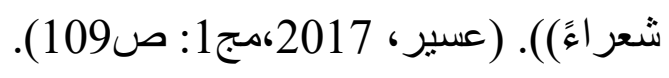

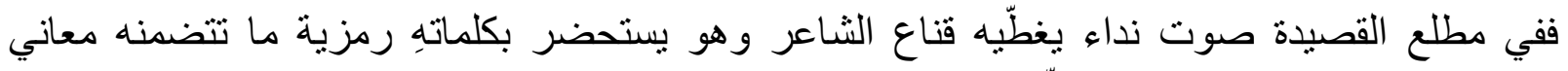

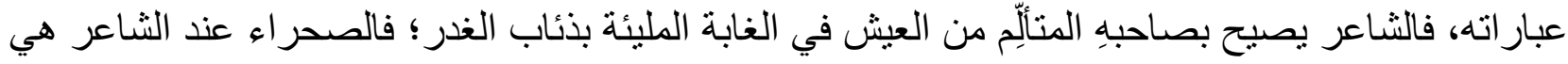

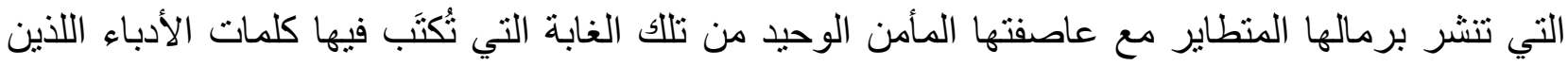

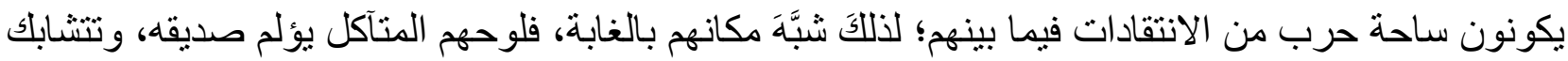

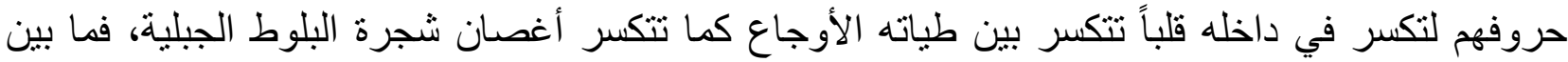

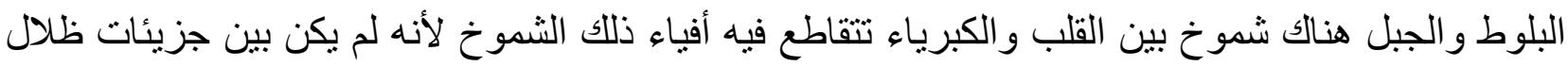

باغتَ عُشباً على السفح

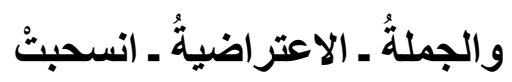

تتسللُ ما بين جذعينِ

تُنهي العبارةُ حالة إحمائها

ويَنَخرِمُ النصُّ ...عشرون سطراً 
تعودُ إلى الأرض....

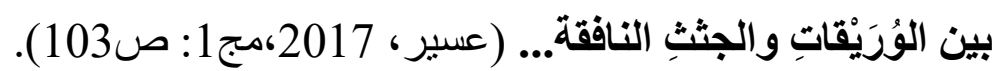

ينتقلُ الثشاعر بانتقالة كلماتهِ (باعتر اضيَّة) ظاهر ها جملة و انسحاب، وباطنها ثورة و وانقلاب، ودعوة لصديقهِ

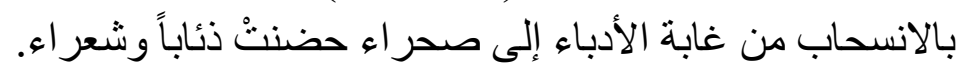
وكذلك يقول:

\section{تجيءُ معي؟}

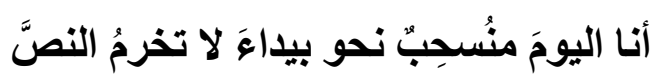

قد تُوجرُ الأنبَب نصلاً لخرقاءَ

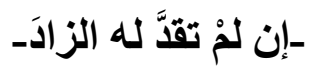

هل ذاك في غابةٍ

تنظاولُ أدغالها...

فتحاجبُ ما يتقاطرُهُ الغصنُ و الغصنُ

حين ينُاقِطُ أثذاعَهُ الضوكُو...

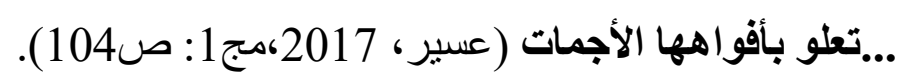

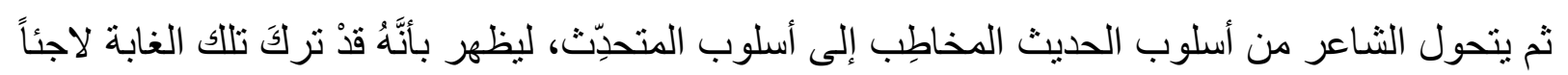

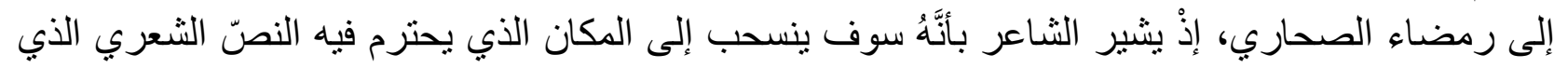

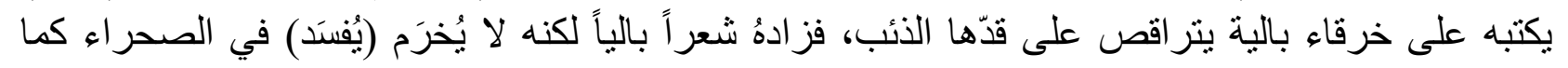

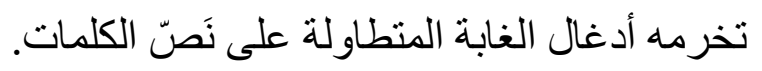

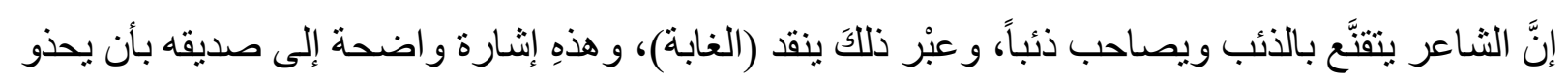
حذوه ويخطو خطاه، فالضوء واضح لمن يتبع النور والثنبي يدر لمن يطلب استندراره. ثم يقول:

وقد تتلاقِقُ ناقوطَهُ المتساقطَ من شحَّةِ الثَي أغصانُها

$$
\text { تبعة تبٌّ تتعالى إلى النورِ... }
$$




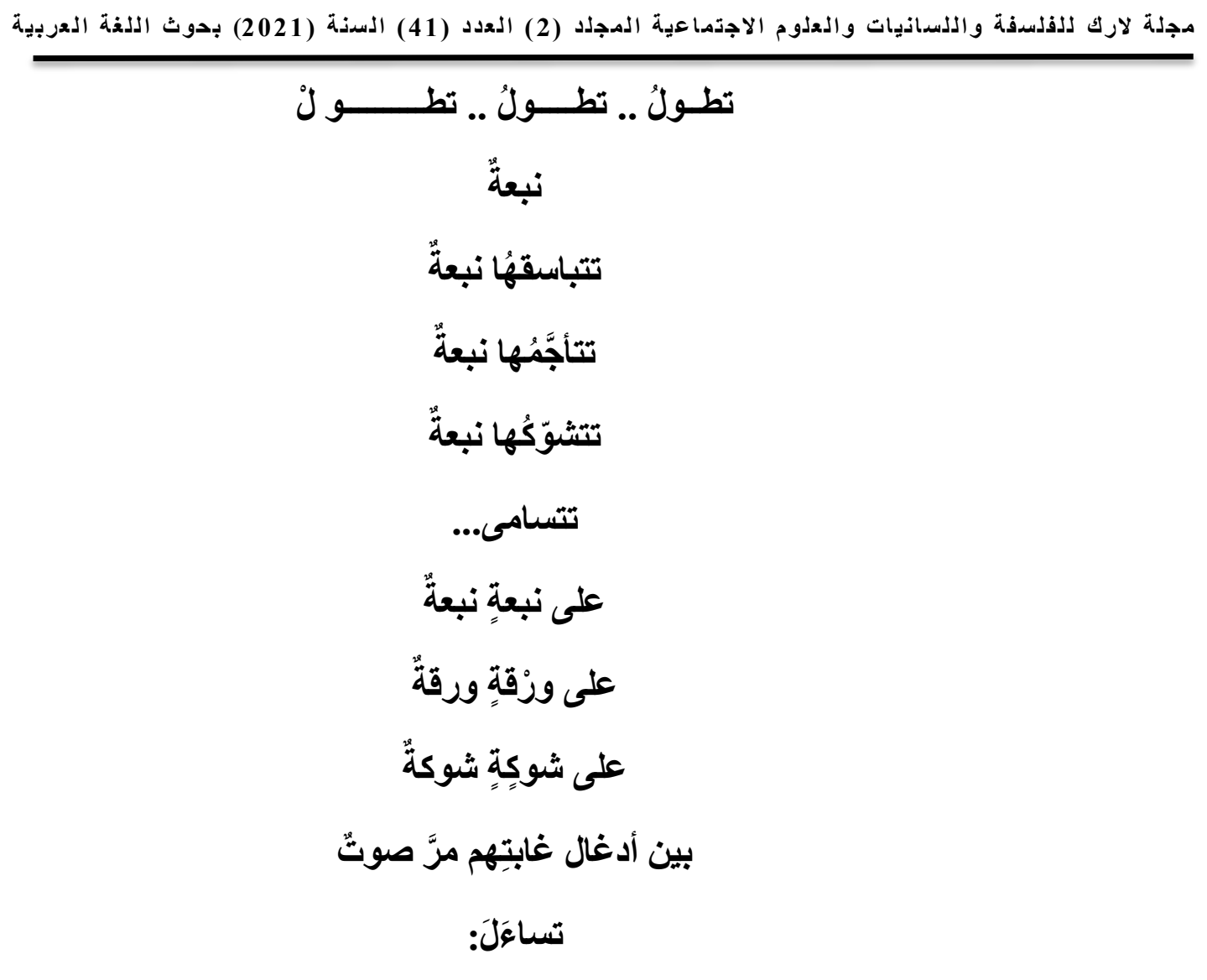

منْ فازَ هذا الصباح بتركيبةِ الضويعِ؟

(ردَّ... - n

ـ " أنا...." شاعرٌ يتلّّى بأعلى الغصون

قابضاً بمخالبِهِ "مثل قوسِ وقوسِِ

يضيقانِ شيئاً فشيئاً" على الكلمات... (عسير، 2017،مج1: ص104، 105).

يفصل الثاعر بأسلوب فردي يستخدم رمزية استفهامية مقنَّعة بأثو الك البراري و أدغال الغابة، وما بين

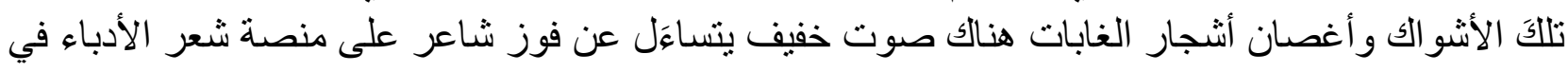

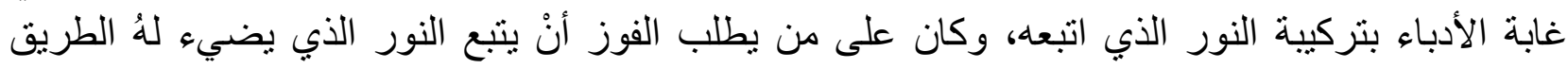

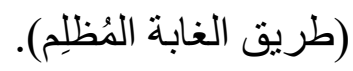

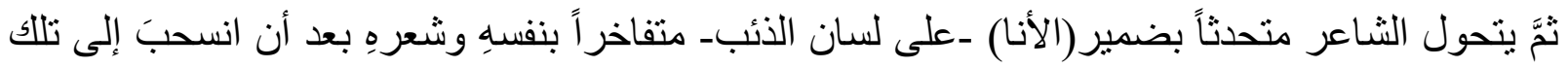

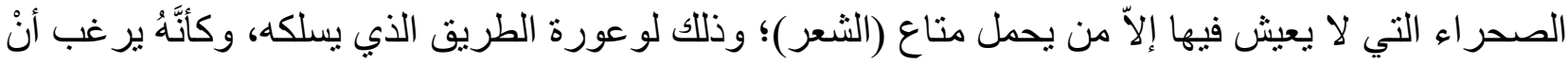

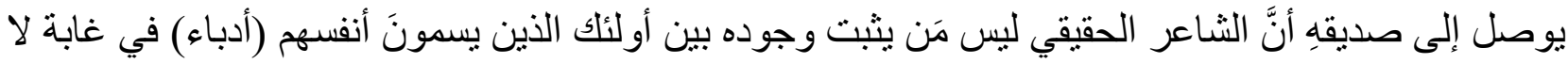

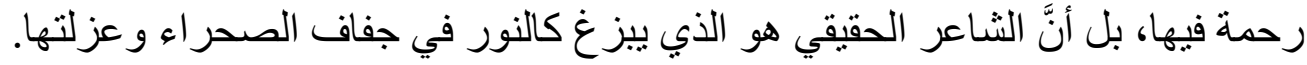

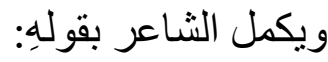




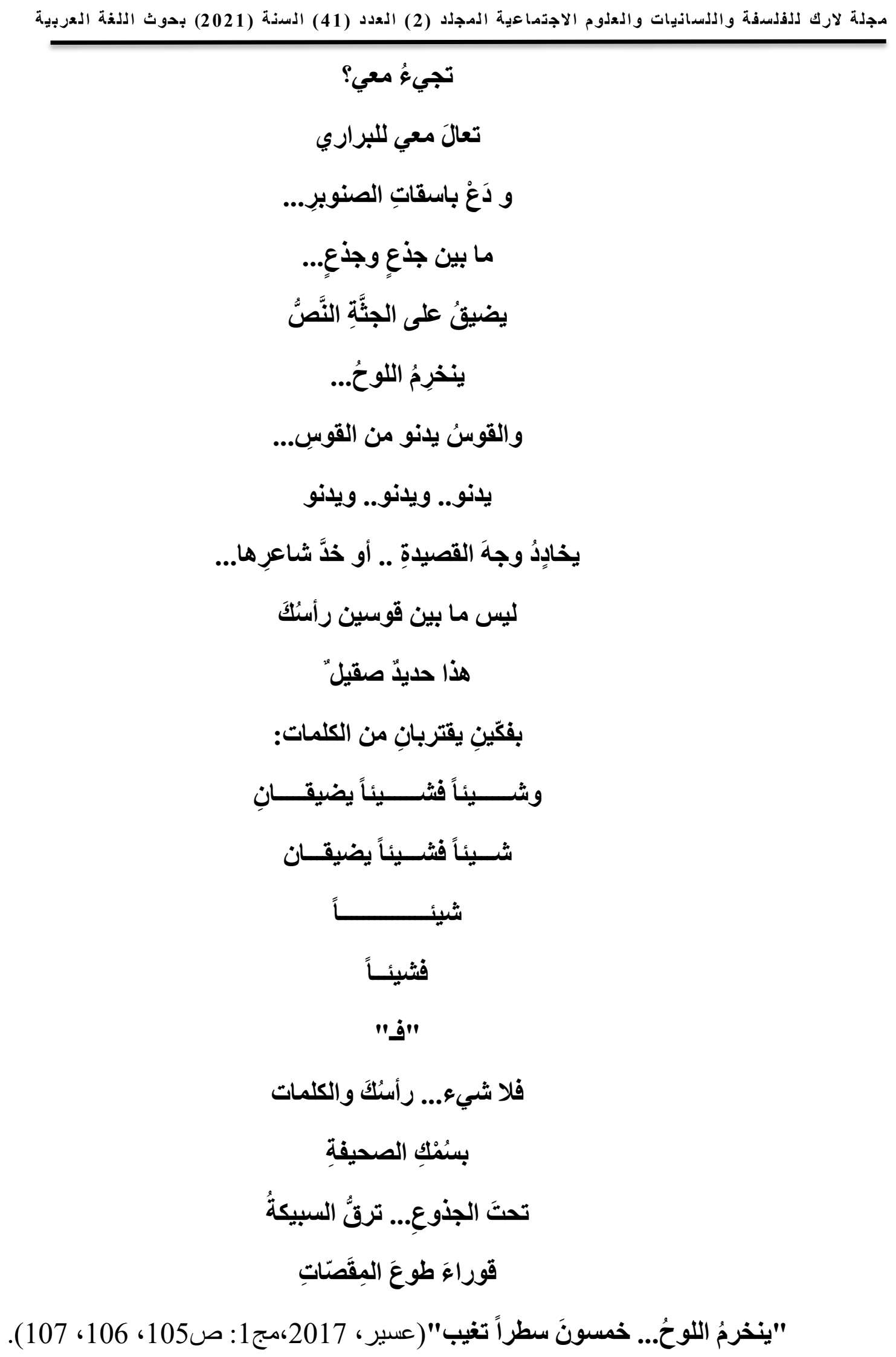




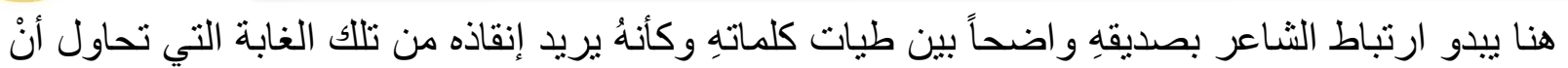
تجعلَ منهُ جذعاً خاوياً وجثة منذورة، والنصَّ الثعري كلمات تحتاج إلى أنْ يكون مُفعماً بالحيوية لا جثنةً خاملة.

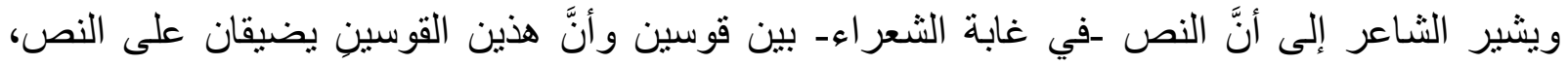

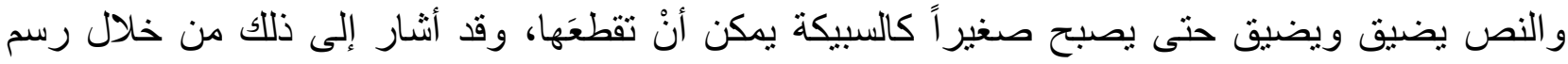

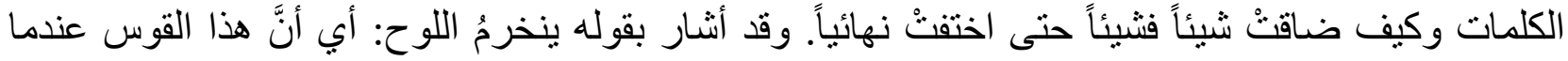

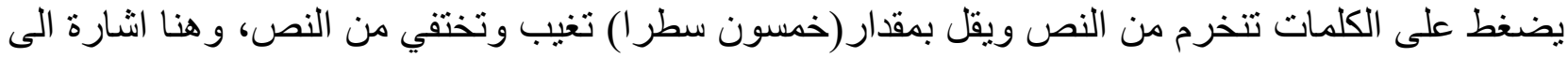
ملحمة كلكامش وقضية انخر ام النصّ المعروفة. فهنا يعبّرِ عن ضيق الغابة وعدم اتِّساعها للشعر اءو و قصائد هم.

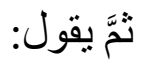

تعال إلى الرملِ يوماً معي

هنا في البراري بكَّ الوحشُ آمنةٌ

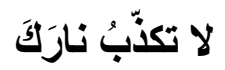

تذكرُ يومَ تَقُُُّل لي الزادَ؟

أو يومَ أو جرنَنَي نصلَ خرقاء؟

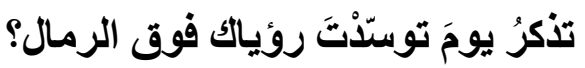

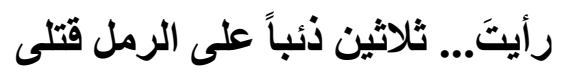

وجمجمةَ الرجلِ المستميثِ بإبدال شـاجورِهِ

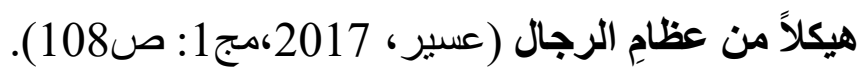

هنا يشير الثاعر إلى حالة الودية بين الذئب و الفرزدق، و الحالة العدو انية بين الذئب و البحتري، فهو يذكر

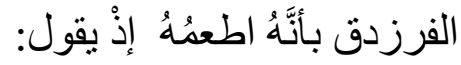

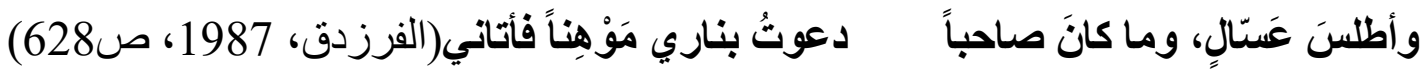

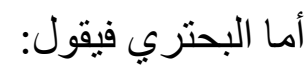

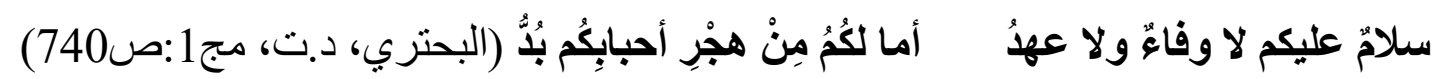
فهو يشير من خلال هذهِ الإحالات إلى أُّنَّ الفرزدق قد أطعم الذٔبَ أما البحتري فقد قتَََهُ. 


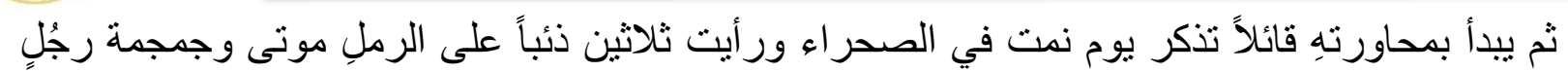

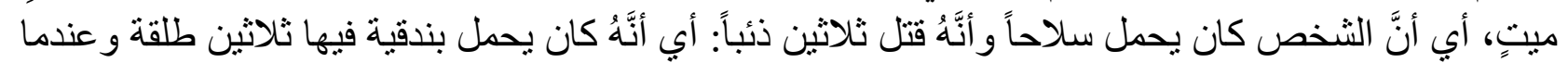

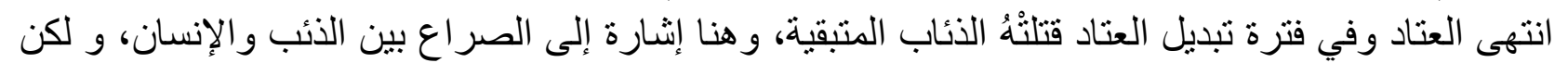

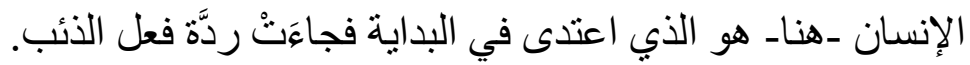

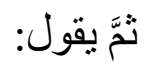

تعال هنا للبراري.... هنا الضبعُ والضبعُ...

ليسنَ كما الغصنُ و الغصنُ

والأُفْقُ ليس كما القوسُ والقوسن

- ... حاثيةُ الأرضِ قوسُ العيونِ الوحيد

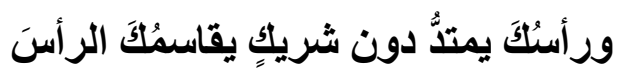

رأسُْكَ يمتدُّ في البرِّ

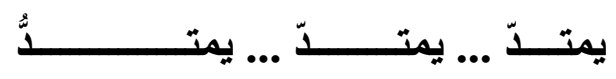

لا حدَّ للبَرِّ

لا حدَّ للر أسِ.... - n

لا حدَّ للكلمات (عسير، 2017،مج1: ص108).

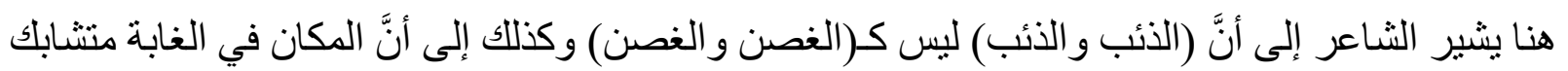

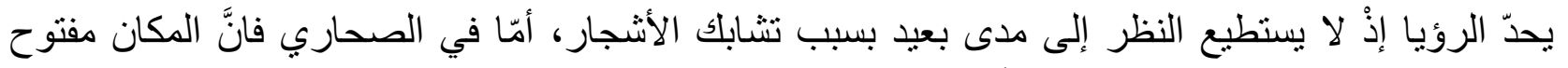

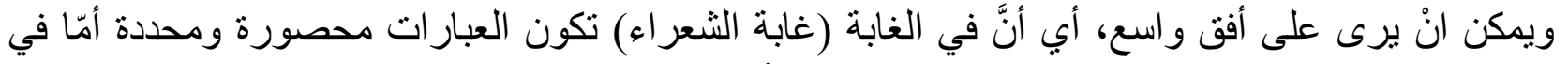

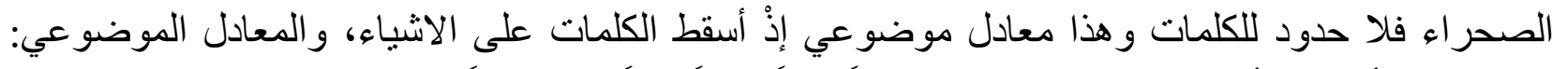

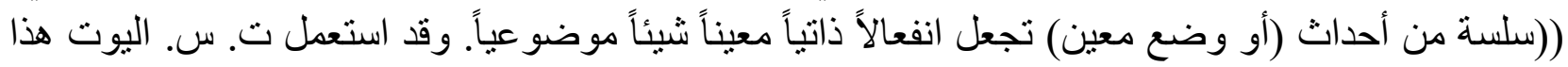

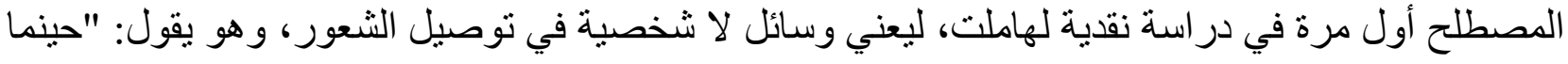

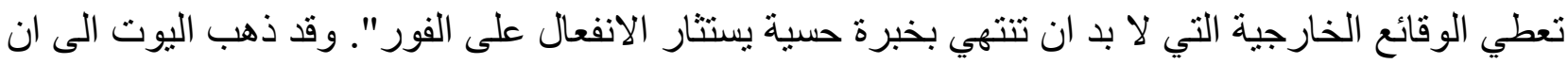

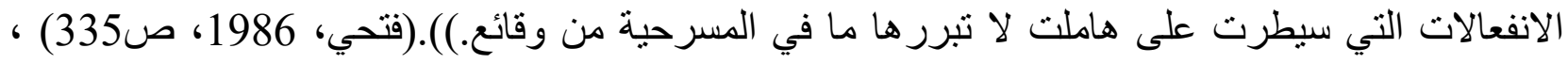

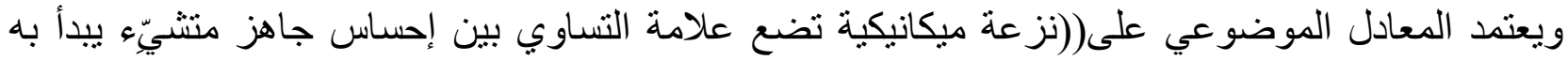

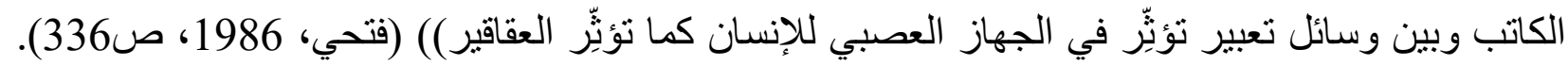

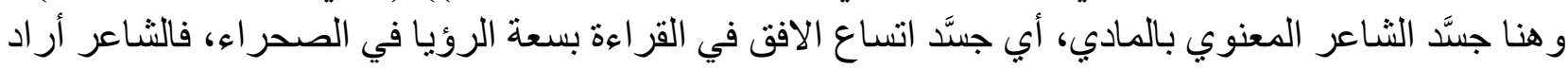

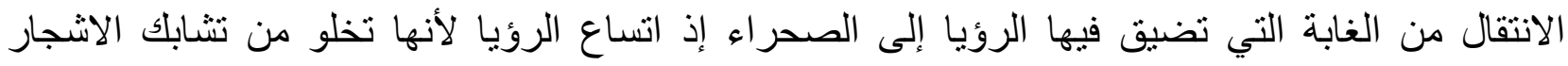


و الغصون، وهو يشير عبْر ذلك إلى ابتعادهِ عن تثابُّك الثعر اء و النقّاد وتناز عهم، وذهابه إلى مكان يتَّع فيه

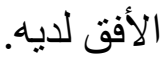

ومن قصائده التي جاءَتْْ على لسان الحيوان، قصيدة يعبر بها عن حقيقة مهمة وهي مصادرة صوت التهان المو اطن في قصيدة (مسحل الزر افات) إذ يقول:

أما وقد أزاحَتِ الأغصانُ الأسدَ عن ظهري؛ سأقودُ زُرافاتي

المستنفرةَ باتجاه الصندوقِ الأخضر الذي يتوستّدُ الغابةً...

$$
\begin{aligned}
& \text { لحظةَ فتح الصندوق... تعالى الـ... } \\
& \text { : الزئيرُ... الصهيلُ.... النعيبُ... } \\
& \text { الخُوار... الثغائُ... العُواء... } \\
& \text { النباحُ... البُغام... اللُواءو... } \\
& \text { الضباحُ... السُّبابُ... الصُّراحُ } \\
& \text { الـ...!!... (عسير، 2017،مج1: ص149). }
\end{aligned}
$$

في هذٍِ القصيدة أبدع الثناعر في اختيار قناعهِ، إذْ تحوَّل القناع الذي اتخذ نموذجاً رمزياً إلى أداة

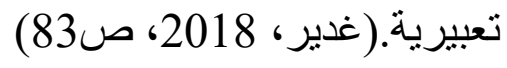

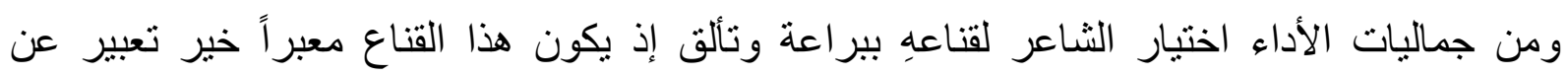

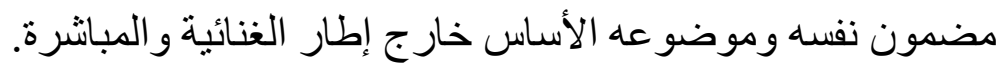

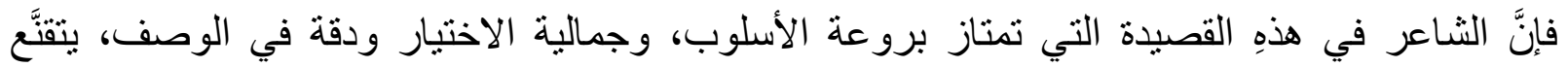

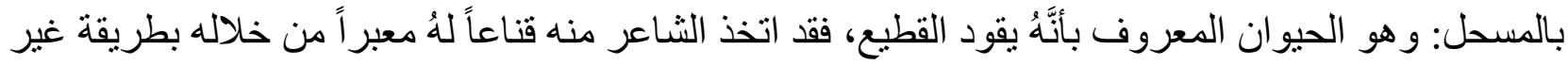
مباثرة عن غايتهِهِ الأساسية التي دفعتُه إلى التقنع.

فإن الثـاعر -من خلال هذهِ القصيدة- أرادَ أنْ ينقل صورة عن الانتخابات في بداياتها إذْ نظهر حرية اختيار الثعب الحاكم المناسب للبلاد.

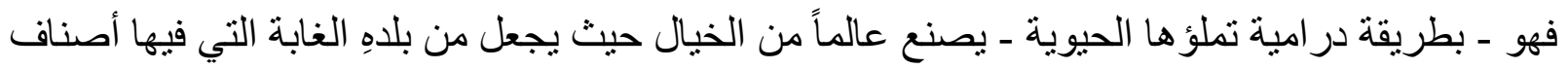

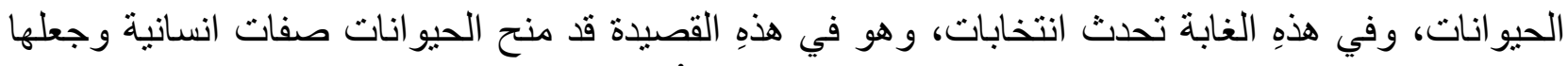

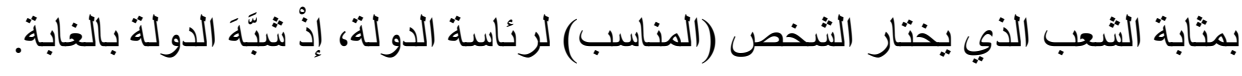

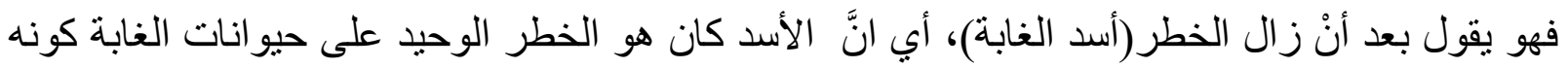

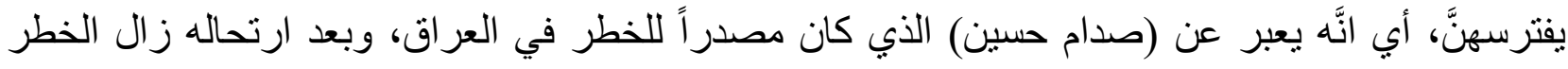


بعض الثيء عن الثعب العر اقي، فظهر ما يعرف بالانتخابات الحُرَّة، فيتوجَّه الشاعر المتقنع بالمسحل الذي يقود الزر افات إلى صندوف الانتخابات وهنا يعبر عن توجه الناس الى ذللك.

كما وقد أشار إلى أنَّهُ عند فتح الصندوق ظهرتْ أصوات المشاركين في الانتخابات، منهم الذئب، ومنهم

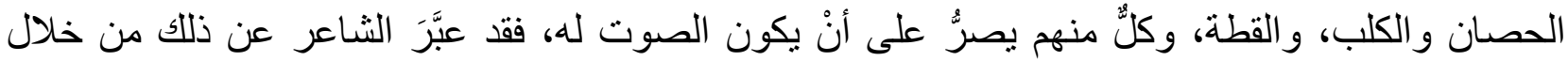

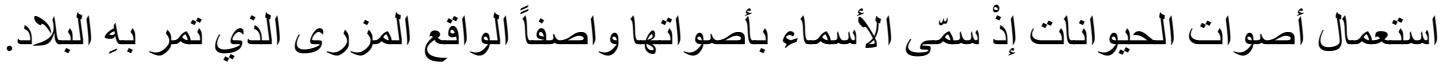

كذلك بقو لهِ:

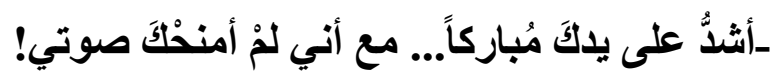

ـ سندخلُ من الثُّبَ العلويّ معاً في الجولِِِ القادمة

أعاد المؤتمرون الغطاعَ على الفوهةِ العُليا قبّل فرارِ الأملِ من

الصندوق مع البَركات الأخرى المتصاعدة (عسير، 2017،مج1: ص149، 150).

إذْ ينتقل الثَاعر إلى صورة أخرى يشثير من خلالها الى أنَّهُ كان يهنئ أعضاء الانتخاب مِن دون أنْ يمنحَهم صونَهُ.

ثُ يوظِّف الثَاعر الاقتباس، و النَّصّ المُقتبَس ـهنا- مأخوذ من رواية (برومثيوس وباندور ا) ففيها يقول الكاتب:

(ان جوينر أرسلَ باندور ا، في إخلاص، ليسعدها بها إنسان وكانتُ تحتفظ بصندوق يحوي هدابا زوجها وكان

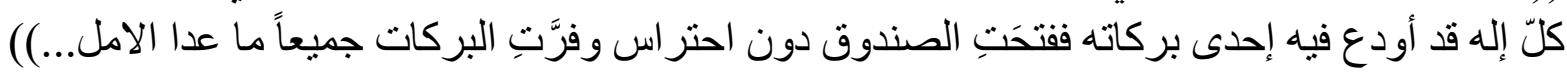

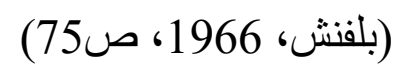

فقد ربط الثاعر بين هذهِ الصورة و صورة صندوق الانتخابات، فإن هذا الصندوق عندما فُتِح طار كلُ شيء ولم يبقَ غير الامل.

في الأجَمات الثابِكة يلتقي:

..الأشبالُ... الحملانُ... المِهارُ... الآرام... الجِراءُ

في صفٍّ واحد... يمارسون لعبة البقاعِ والرحيل

*

في الصفت القريبِ من الغابة... 
يسمعُ صغارُ آدم صوتَّ المعلّمّ عالياً:

ـ قبَل بدِعِ التصويتِ... مَنْ منكم... أحبائي

يستطيع أنْ يخبرني...

: ماذا يُطَلَقُ على صوتِ الزرافةُ؟

لم تتعالَ كلٌّ السباباتِ بسينِ أستاذِها...

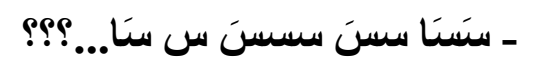

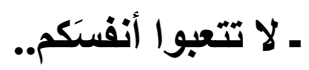

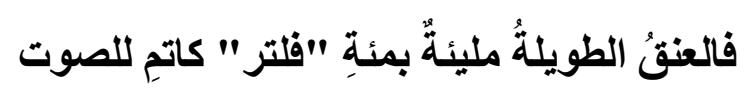

\section{والآن نبدأ التصويت؟؟ (عسير، 2017،مج1: صنئ150، 151).}

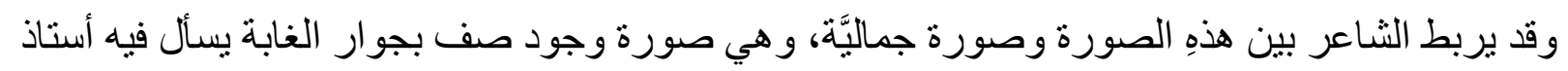

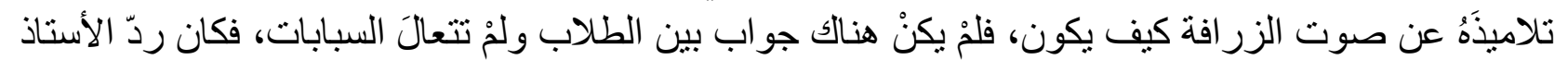
أنَّ عنق الزر افة طويل لا يسمح للصوت بات بالخروج.

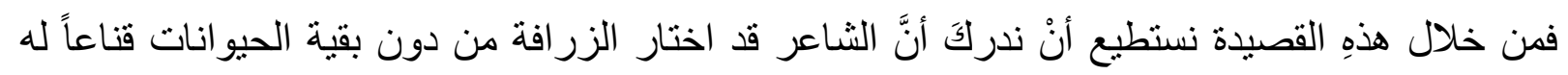

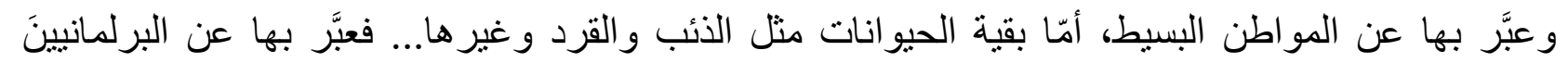

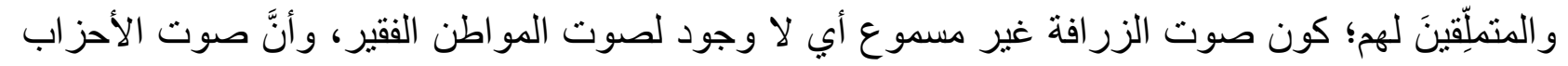

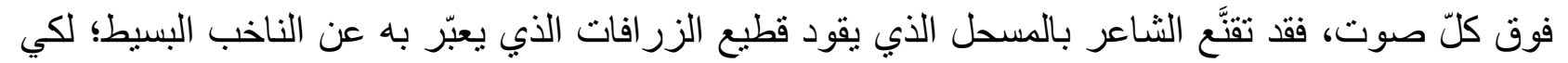
يشير إلى صوت صلى صوت فلناخب المصادَر الإر ادة...

و هكذا زخرتُّ قصيدة القناع على لسان الحبوان بالمعاني الخفيَّة وعبَّرَتْْ عن خلجات نفس الثَاعر.

الخاتمة:

إنَّ مِنْ أهمّ النتائج التي نوصَّلَ لها البحث: - -

1- القناع إحدى الوسائل التي لجأ إليها الثعر اء في العصر الحديث، واستمروا على هذهِ الاتقانة حتى وإنى

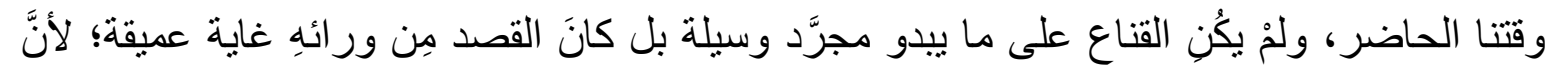

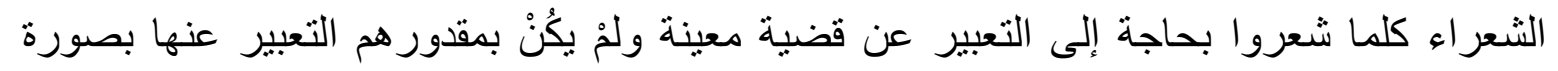

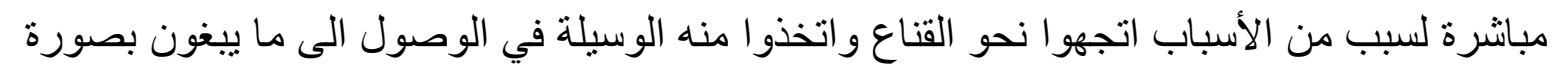
غبر مباشرة.

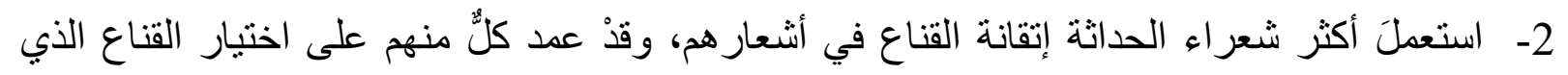

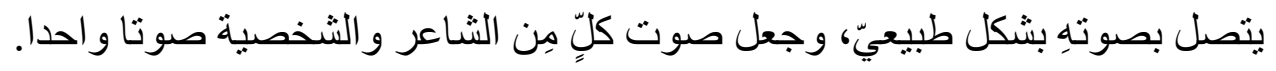




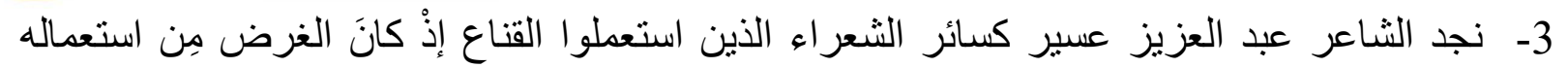

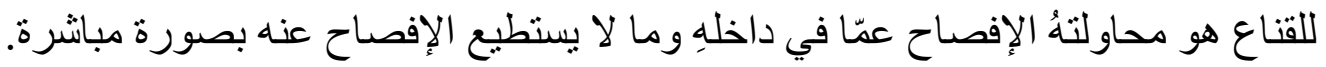

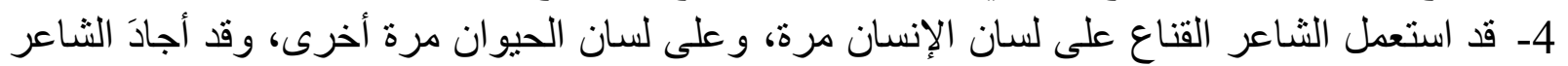

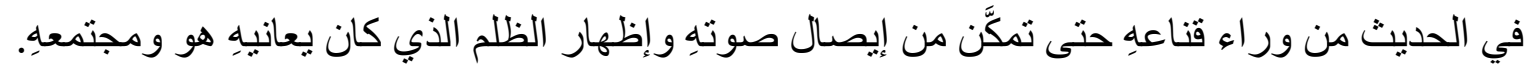

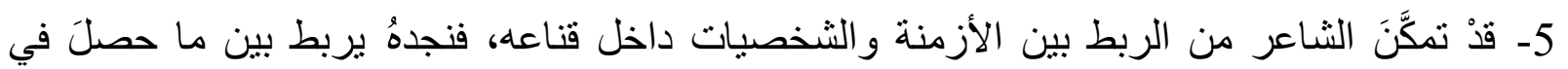

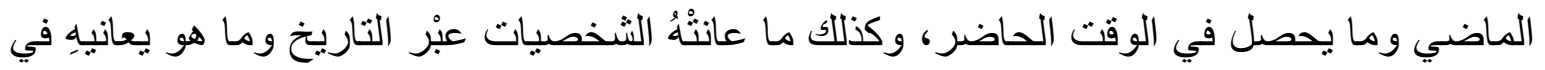
زمانهِ. 6- يُلاحَظ في أثنعارِهِ كثرة الإحالات من الثُعر اء و القرآن الكريم والروايات محاو لاً من خلال ذلك رسم

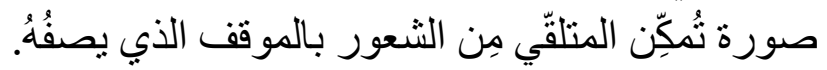

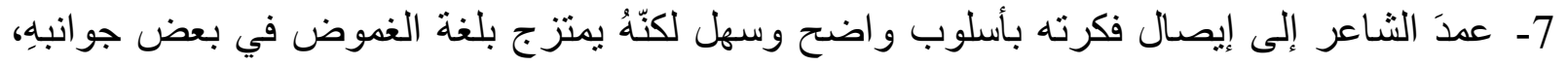

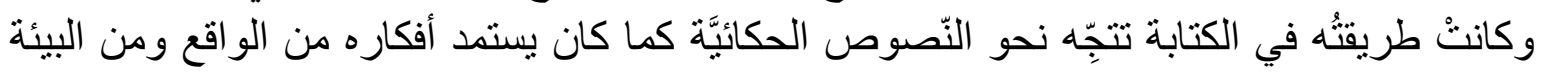

التي بعيش فيها.

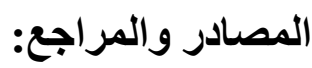

[1] القر آن الكريج.

[2] الأسمر (راجي)، المُعجَم المُفصَّل في علم الصَّرف، مراجعة: إميل بديع يعقوب، دار الكتب العلمية، بيروت_لبنان، 1997م.

[3] أطيمش (محسن)، دير الملاك، دار الرشيد للنشر، بغداد، 1982م.

[4] أندرسن (هانس كريستيان)، ملابس الامبر اطور الجديدة، ترجمة: توفيق علي منصور، الدار المصرية اللبنانية، الطبعة الأولى، 2014م.

[5] البحتري، ديو ان البحتري، تحقيق:حسن كامل الصيرفي، دار المعارف، القاهرة، الطبعة الثالثة، د.ت. [6] بلفنش، عصر الأساطير، ترجمة: رشدي السيسي، راجعه: صقر خفاجة، دار النهضة العربية، القاهرة، 1966

[7] ثامر (فاضل)، مدار ات نقدية في اشكالية النقد والحداثة والإبداع، دار الثؤون الثقافية العامة، بغداد، الطبعة الأولى، 1987 م.

[8] الرباعي (ربى عبد القادر)، البلاغة العربية وقضايا النقد المعاصر، دار الجديد، لبنان، الطبعة الأولى، 2011 
[9] الرواشدة (سامح عبد العزيز)، القناع في الثعر العربي الحديث: دراسة في النظرية و التطبيق، الصايل للنشر و التوزيع، عمّان، 2013م. [10] الرويلي (ميجان)، البازعي (سعد)، دليل الناقد الأدبي، المركز الثقافي العربي، الدار البيضاءـ المغرب، الطبعة الخامسة، 2007م.

[11] شمسي (حسن جبار محمد)، ملامح الرمز في الغزل العربي القديم (در اسة في بنية النص ودلالاته

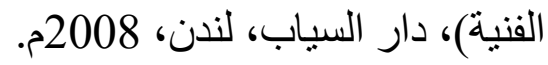

[12] العامري (كامل عويد)، معجم النقد الأدبي الحديث، دار نينوى للار اسات والنشر والتوزيع، دمشت، الطبعة الأولى، 2018م.

[13] عباس (إحسان)، اتجاهات الثعر العربي المعاصر ، عالم المعرفة، الكويت، 1978م. [14] عسير (عبد العزيز)، الثاشـة ما بعد الورقة، شركة الغدير للطباعة والنشر، العراقـالبصرة، الطبعة الأولى، 2017م.

[15] علوش (سعيد)، معجم المصطلحات الأدبية المعاصرة، دار الكتاب اللبناني،بيروت /سوشبريس، الدار

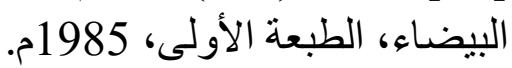

[16] غدير (ناظم عودة)، اللغة المُقَنََّة: المواجَهات الرَّمزيَّة بين النَّص والسلطة، دار كنوز المعرفة للنشر و التوزيع، عمّان، الطبعة الأولى، 2018م.

[17] فتحي (ابر اهيم)، معجم المصطلحات الأدبية، التعاضدية العمالية للطباعة والنَّثر، الجمهورية التونسية، 1986م.

[18] الفرزدق، ديو ان الفرزدق، شرحهُ وضبطهُ وقدَّم له: علي فاعور، دار الكتب العلمية، بيروت_لبنان، الطبعة الأولى، 1987م.

[19] القاضي (محمد) ومجموعة من المؤلفين، معجم السرديات، الرابطة الدولية للناشرين المستقلين، الطبعة الأولى، 2010م.

[20] القط (عبد القادر)، فنّ المسرحيّة، دار نوبار / الثركة المصرية العامة للنشر ـ لونجمان -، مصر ، الطبعة الأولى، 1988 م.

[21] محسن (فهد)، الثعر الحديث في البصرة1947-1995 در اسة فنية، دار الثؤون الثقافية العامة، بغداد، الطبعة الأولى، 2007م. [22] مطلوب (أحمد)، معجم المصطلحات البلاغية و تطوّر ها، مكتبة لبنان ناشرون، بيروتـ لبنان، 2007م. [23] ابن منظور، لسان العرب، مؤسسة الأعلمي للمطبو عات، بيروتـ لبنان، الطبعة الأولى، 2005م. 


$$
\text { مجلة لارك لدفلسدة واللسدانيات و العلوم الاجتماعية المجلد (2) العدد (41) السذة (2021) بحوث اللغة الدربية }
$$

[24] موسى (سلامة)، نظرية التطوّر وأصل الإنسان، مؤسسة هنداوي للتعليم و الثقافة، مصر ، 2012م.

[25] وادي (طه)، جماليات القصيدة المعاصرة، الثركة المصرية العامة للنشر، لونجمان، الطبعة الأولى، 2000م.

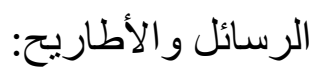

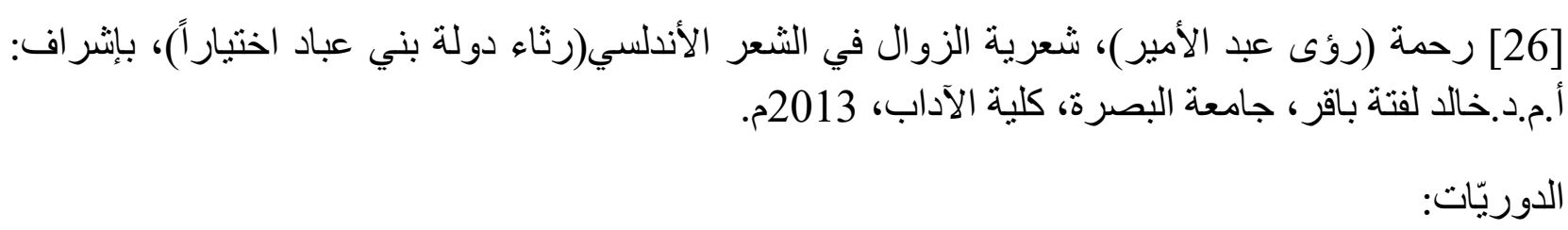
[27] إبر اهيم (عبد العزيز)، أقنعة النَّصّ الروائيّ، مجلة أقلام، العدد2، السنة التاسعة والأربعون، 2014م.

\section{Sources and references:}

Books:

The Qur'an]1[

[2] Al-Asmar (Raji), The Detailed Dictionary in The Science of Drainage, review: Emile Badie Yaacoub, Scientific Book House, Beirut-Lebanon, 1997.

Atmesh (Mohsen), Deir al-Malak, Al-Rasheed Publishing House, Baghdad, 1982. [3]

[4] Andersen (Hans Christian), The Emperor's New Clothes, Translated by Tawfiq Ali Mansour, Egyptian-Lebanese House, First Edition, 2014.

[5] Al-Bahtri, Diwan al-Bahtri, Investigation: Hassan Kamel Al-Serfi, Dar al-Knowledge, Cairo, Third Edition, D.T.

[6] Belfinch, Age of Legends, translation: Rushdie El Sisi, see: Saqr Khafaja, Arab Renaissance House, Cairo, 1966.

[7] Thamer (Fadhil), Critical Orbits in The Problem of Criticism, Modernity and Creativity, House of Public Cultural Affairs, Baghdad, First Edition, 1987.

[8] Al-Rubai (Ruba Abdel Kader), Arabic Rhetoric and Contemporary Criticism Issues, Dar alJadid, Lebanon, First Edition, 2011.

[9] Al-Rawashada (Sameh Abdul Aziz), The Mask in Modern Arabic Poetry: A Study in Theory and Practice, Sayel Publishing and Distribution, Amman, 2013. 
[10] Ruwaili (Meghan), Bazai (Saad), Literary Critic's Guide, Arab Cultural Centre, CasablancaMorocco, 5th edition, 2007.

[11] Shamsi (Hassan Jabbar Muhammad), features of the symbol in the ancient Arabic yarn (a study of the structure of the text and its artistic connotations), Dar al-Sayab, London, 2008 .

[12] Al-Ameri (Kamel Aweid), Dictionary of Modern Literary Criticism, Nineveh Studies, Publishing and Distribution, Damascus, First Edition, 2018.

[13] Abbas (Ihsan), Trends in Contemporary Arabic Poetry, World of Knowledge, Kuwait, 1978.

[14] Assir (Abdul Aziz), Post-Paper Screen, Al-Ghadeer Printing and Publishing Company, IraqBasra, First Edition, 2017.

[15] Alloush (Said), Dictionary of Contemporary Literary Terms, Lebanese Book House, Beirut/Swashpress, Casablanca, First Edition, 1985.

[16] Ghadir (Nazim Odeh), Masked Language: Symbolic Confrontations between Text and Power, Treasures of Knowledge Publishing and Distribution, Amman, First Edition, 2018.

[17] Fathi (Ibrahim), Dictionary of Literary Terms, Labour MutualIsm for Printing and Publishing, Republic of Tunisia, 1986.

[18] Al-Faradaq, Diwan al-Faradiq, explained and controlled it and presented it to him: Ali Faour, Scientific Book House, Beirut-Lebanon, first edition, 1987.

[19] Judge (Muhammad) and a group of authors, Narrative Dictionary, International Association of Independent Publishers, First Edition, 2010.

[20] The Cat (Abdelkader), The Art of The Play, Nobar House/Egyptian Public Publishing Company - Longman- Egypt, First Edition, 1988.

[21] Mohsen (Fahd), Modern Poetry in Basra 1947-1995 Art Study, House of Public Cultural Affairs, Baghdad, First Edition, 2007.

[22] Ahmed, Dictionary and Development of Rhetorical Terms, Library of Lebanon Publishers, Beirut- Lebanon, 2007.

[23] Ibn Mansoor, Tongue of the Arabs, Al-Adly Publishing Foundation, Beirut- Lebanon, first edition, 2005.

[24] Musa (Salama), Theory of Evolution and The Origin of Man, Hindawi Foundation for Education and Culture, Egypt, 2012.

[25] Wadi (Taha), Aesthetics of Contemporary Poem, Egyptian Public Publishing Company, Longman, First Edition, 2000. 
Treatise and Thesis:

[26] Rahma (Ro'aa Abdul-Ameer), The Poetry of The Ephemeral in Andalusian Poetry (The Lamentation of the State of Bani Abad of Choice), under the supervision of: A.M.D. Khaled Fata Baqir, Basra University, Faculty of Arts, 2013.

Patrols:

[27] Ibrahim (Abdul Aziz), Novel Text Masks, Pens Magazine, Issue 2, Year 49, 2014. 